
\title{
25 Research Square \\ Effect of Daidzein on the Proliferation of Lung Cancer Cells Involved in the Apoptotic Signaling Pathway
}

Hui Liu

Jiujiang Medical College: Jiujiang University Medical College

Xiaobo Wang

Jiangxi Tumor Hosp

Ouyang Jin

Jiujiang Medical College: Jiujiang University Medical College

Denggang Fu

Jiujiang Medical College: Jiujiang University Medical College

You Peng

Jiujiang Medical College: Jiujiang University Medical College

Chengquan Cheng

Nanchang University Second Affiliated Hospital

Xiaowei Xiong

Jiujiang Medical College: Jiujiang University Medical College

Shaoxin Huang

Jiujiang Medical College: Jiujiang University Medical College

xin wang ( $\square$ wangxin2813@163.com )

Jiujiang Medical College: Jiujiang University Medical College https://orcid.org/0000-0003-2168-7588

\section{Research}

Keywords: Isoflavone, Daidzein, Lung adenocarcinoma cells, Apoptosis, P53 signaling pathway

Posted Date: December 17th, 2020

DOI: https://doi.org/10.21203/rs.3.rs-127789/v1

License: (c) (i) This work is licensed under a Creative Commons Attribution 4.0 International License.

Read Full License 


\section{Abstract}

Background: Daidzein is one of the key bioactive substances of soybean isoflavones that has a wide range of health benefits includes antineoplastic. Epidemiological evidence suggests that soy glycogen is associated with the incidence and prognosis of lung cancer. we purposed to assess the effect and molecular mechanism of daidzein on lung cancer, and to maximize therapy outcome for individualized treatment.

Methods: In this report, $\mathrm{H} 1299$ were cultured in a medium with $10 \mu \mathrm{M}$ daidzein for 6 hours, we detected the expression level of apoptosis-related genes in H1299 by cDNA microarray analysis. The selected genes were further validated by using RT-PCR analysis and Western blot. Finally, We usedflow cytometry to detect cell cycle alterations, and apoptosis the proliferation and apoptosis in HELF and H1299 cells were detected by Cell counting kit-8 assays.

Results: These results indicate that low concentrations of isoflavone crude extract and daidzein could significantly affect the proliferation of H1299 (Human lung adenocarcinoma) and HELF (Human embryonic lung fibroblast) cells. The results of microarray in our study suggest that apoptosis-related genes are up-regulated induced by daidzein in H1299 cells and verified by RT-qPCR, particularly TP53 and caspase9. Western blotting shows the effect of daidzein on P53 and caspase9 in HELF cells be more obvious than it in H1299 cells. While the expression of TP53 was suppressed by pifithrin-a (PFTa) in HELF and H1299 cells, the mRNA and protein expression of TP53 still increase induced by daidzein, also, the effect of apoptosis induced by daidzein is involved in the P53 apoptosis pathway through inhibition of TP53 gene expression by PFTa.

Conclusions: In conclusion, daidzein affected proliferation and apoptosis in HELF and H1299 cells, and the mechanism of apoptosis involved in the P53 signaling pathway.

\section{Background}

Non-small cell lung cancer (NSCLC) is one of the frequently diagnosed malignancies with high mortality worldwide,accounting for nearly $85 \%$ of all lung cancer cases(1). Previous evidence indicates that dietary factors have an important influence on the development and prognosis of tumors(2, 3). Further, soy food consumption contributes to reducing the incidence of lung cancer risk, particularly for aggressive tumors(4-6).

Daidzein, also named 7-hydroxy-3-4-hydroxyphenyl chromen-4-one, belongs to the group of isoflavones and is characterized by phytoestrogen, anti-inflammatory, anti-oxidative and anti-dysrhythmic activities(7, 8). Epidemiological evidence has revealed that soy foods and isoflavones (daidzein and genistein) are associated with a reduced risk of cancer $(9,10)$.

Human gene expression microarrays have increasingly become a powerful tool for large-scale analysis of the biological process in a specific condition, providing insight into gene expression change related to the 
response to an intended purpose(11). TP53 is a tumor suppressor gene and plays an essential role in protecting the genome against oxidative damage(12). Transcriptional activation by p53 of proapoptotic Bax and Bak can enhance the permeability of the mitochondrial membrane, which in turn results in the release of apoptogenic factors(13). Caspase-9 is an apoptotic initiator protease of the intrinsic or mitochondrial apoptotic pathway, which is activated at multi-protein activation platforms(14).

Also, the potential mechanism and effect of soy isoflavones or daidzein on lung cancer were still unclear. In this study, we used lung cells as a vitro model to study the antineoplastic activities of isoflavone crude extract and daidzein. The gene expression profiling of the cells treated by these substances is analyzed and attempt to explain the molecular mechanism of the impact of daidzein on the proliferation of human lung adenocarcinoma cells. In this study, we used gene chip technology and molecular experimental technology to explore the effect and molecular mechanism of daidzein on lung cancer. This will provide a theoretical basis for the development of daidzein into health products.

\section{Methods}

\section{Cell culture and treatment}

HELF (Normal human embryonic lung fibroblast) and H1299 (Human lung adenocarcinoma) cells (Obtained from ATCC, Manassas, VA, USA) were incubated with Isoflavone crude extract(15) $(100 \mu \mathrm{g} / \mathrm{L})$ (supplied by You Peng, Jiangxi province engineering research center of ecological chemical industry, Jiujiang university) and daidzein (DD, $10 \mu \mathrm{M})$ (purchased from Sigma-aldrich, St. Louis, MO, USA) was added to the wells. In the case of the pifithrin-a (PFTa) treatment, $10 \mu \mathrm{M}$ pifithrin-a (Selleck chemicals, Houston, USA) was mixed to the cells incubate $6 \mathrm{~h}$ with the treatment of $10 \mu \mathrm{M}$ daidzein.

\section{Cell Proliferation Assays}

For CCK8 assay, H1299 and HELF cells were seeded in a 96-well plate at a density of 2000 cells/well; until the wells were covered by cells about $80 \%$, the treatment $(100 \mu \mathrm{g} / \mathrm{L}$ isoflavone crude extract, $10 \mu \mathrm{M}$ daidzein, $10 \mu \mathrm{M}$ pifithrin-a) were added and incubated for $6 \mathrm{~h}$, and controlled with non-treatment or pifithrin-a only. Briefly, after stimulation, the cells in 96-well plates were added with $10 \mu \mathrm{L}$ of CCK8 solution in the culture medium and were incubated for another 1 hour at $37^{\circ} \mathrm{C}$ in a humidified environment containing $5 \% \mathrm{CO}_{2}$. Absorbance was measured at $450 \mathrm{~nm}$ using Spectramax $\mathrm{M} 2$ microplate readers (Molecular devices, sunnyvale, CA). Each operation repeats at least three times.

\section{Flow Cytometry}

$\mathrm{H} 1299$ and HELF cells were cultured with a medium that contains $100 \mu \mathrm{g} / \mathrm{L}$ isoflavone crude extract or $10 \mu \mathrm{M}$ daidzein for 6 hours at $37^{\circ} \mathrm{C}$ respectively. As control groups, we culture cells at the medium without the isoflavone crude extract or daidzein. Then, remove the cell medium and add $100 \mu \mathrm{L} /$ well/6- 
well plate of $4 \%$ formaldehyde fixative buffer (not supplied) to each well. Remove fixative after incubating plates for 30 minutes at room temperature. And then wash the cells 3 times with PBS. Add $50 \mu \mathrm{L}$ of the reaction mixture to each well or tube and incubate at $37^{\circ} \mathrm{C}$ for 60 minutes. Remove the reaction mixture, and wash the cells 5 times with PBS, monitor the fluorescence intensity by flow cytometer. Similarly, the flow cytometry operations of $\mathrm{H} 1299$ and HELF cells treat with $10 \mu \mathrm{M}$ pifithrin-a and $10 \mu \mathrm{M}$ daidzein using the same method and compared with add pifithrin-a (PFTa) only. Each operation repeats at least three times.

\section{Microarray}

$\mathrm{H} 1299$ were cultured in a medium with $10 \mu \mathrm{M}$ daidzein for 6 hours, and total RNA was extracted from the H1299 cells using TRIzol reagent (Invitrogen, Life technologies, USA) according to the manufacturer's protocol. Then total RNA was used to synthesize double-stranded complementary DNA (cDNA). Doublestranded cDNA was labeled and hybridized to the $4 \star 180 \mathrm{~K}$ Agilent human RNA Array V4. The array contains 34,000 human mRNAs. These RNA target sequences were merged from the existing databases, such as RefSeq and Ensembl. After hybridization and washing, the processed slides were scanned with the Agilent G2565CA microarray scanner. The mRNA array data were analyzed for data summarization, normalization, and quality control by using the Genespring software v.11.5 (Agilent technologies, Inc). To select the differentially expressed genes, we used threshold values of $\geq 2$ and $\leq-2$-fold change and a Benjamini-Hochberg corrected P-value of 0.05. The data were log2 transformed and median centered by genes using the Adjust data function of CLUSTER 3.0 software (University of Tokyo, Human genome center, Tokyo, Japan), then the average linkage hierarchical clustering algorithm was used as visualization.

\section{Real-time Qpcr}

H1299 and HELF cells were cultured in 6 well plates, treat with $10 \mu \mathrm{M}$ daidzein to an optimal density. And single $10 \mu \mathrm{M}$ pifithrin-a as a control group when treatment of the experiment group contain $10 \mu \mathrm{M}$ pifithrin- $a$ and $10 \mu \mathrm{M}$ daidzein. Total RNA was extracted using the TRizol reagent method (Invitrogen, Life technologies, USA). The total RNA concentration and the quality was determined using Spectra max M2 microplate readers (Molecular devices, Sunnyvale, CA). The following primers (both of H1299 and HELF cells) were designed by Primer Blast for determined the relative expression of the human TP53 gene. Forward primer: 5'-TTATCTGTTCACTTGTGCCC-3', reverse primer: 5'-TCATGTGCTGTGACTGCTTG-3'. For human Caspase9 gene expression, forward primer: 5'-GCCAACCCTAGAAAACCTTACCC-3', reverse primer: 5'-TCACCAAATCCTCCAGAACCAA-3'. For human $\beta$-actin gene expression, forward primer: 5 'GCCCAGAGCAAGAGAGGTAT-3', reverse primer: 5'-GGCCATCTCTTGCTCGAAGT-3'.

Reverse transcription was carried out on total RNA in a final volume of $20 \mu \mathrm{L}$ RT reactions using the Easyscript ${ }^{\circledR}$ One-step gDNA Removal and cDNA Synthesis SuperMix kit (TransGen Biotechnology, Beijing, China) according to the manufacturer's instructions. RT-qPCR was performed using TransStart Top Green 
qPCR SuperMix (Transgen biotechnology, Beijing, China). The RT-qPCR reaction system ( $20 \mu \mathrm{L})$ contained $10 \mu \mathrm{L}$ TransStart ${ }^{\circledR}$ Top Green qPCR $2^{\star}$ SuperMix and $2 \mu \mathrm{L}$ cDNA synthesis reaction mixture. The amplification condition was $94^{\circ} \mathrm{C}$ for $30 \mathrm{~s}$, immediately followed by 40 cycles of amplification $\left(94^{\circ} \mathrm{C}\right.$ for $5 \mathrm{~s}, 50^{\circ} \mathrm{C}$ for $15 \mathrm{~s}, 72^{\circ} \mathrm{C}$ for $10 \mathrm{~s}$ ).

The results were normalized to the expression level of $\beta$-actin before the comparison of the relative levels of expression between treatment and control groups. Each operation repeats at least three times.

\section{Western Blot Analysis}

Western blot analysis

To confirm the difference in protein expression between the group of control (blank control or PFTa only) and the group of the experiment ( $10 \mu \mathrm{M}$ daidzein or both of $10 \mu \mathrm{M}$ daidzein and $10 \mu \mathrm{M} \mathrm{PFTa})$ in $\mathrm{H} 1299$ and HELF cells, $5^{\star} 10^{6}$ cells were harvested and lysed in a lysis buffer total protein extraction buffer (TPEB) with protease inhibitor (Transgen, Beijing, China). The concentration of extracted proteins was determined using a Qubit ${ }^{\text {TM }}$ Flourocytometer (Invitrogen, USA) by loading equal amounts of protein onto each well of the Nu PAGE Bis-Tris Gel (Invitrogen, USA). Western blotting revealed the relative expression level of caspase9 in NSCLC cells line H1299 and normal lung cells HELF for control. All experiments were performed in triplicate. Each bar represents the mean of three independent experiments.

\section{Statistical analysis}

Each experiment analysis was independently repeated at least three times. Data were analyzed by standard Analysis of variance (ANOVA) techniques, followed by a Least-squares difference (LSD) comparison of mean data values at a P-value of 0.05 , using SPSS 20.0 software.

\section{Results}

The effect of soy isoflavone crude extract and daidzein on the proliferation of normal and lung cancer cells

The effects of daidzein on the proliferation of HELF and H1299 cells were evaluated by CCK8 assay, which measures the impedance of the attached cells to determine cell viability.

We found a significant proliferation promoted for $10.00 \%$ (95\% Cl: $2.66,17.336, \mathrm{P}=0.037)$ when the concentration increase 10 times from 10 to $1000 \mu \mathrm{g} / \mathrm{L}$ in HELF cells, an average increase of $64.5 \% \pm 0.71$ in $10^{-1}$ and $1 \mu \mathrm{g} / \mathrm{L}$ isoflavone crude extract in H1299 cells (Fig. 1a). Cellular activity increases by an average of $5.06 \%(95 \% \mathrm{Cl}: 1.95,8.18, \mathrm{P}=0.009)$ per hour in $\mathrm{HELF}$ cells treated with $100 \mu \mathrm{g} / \mathrm{L}$ isoflavone crude extract from 0 to 24 hours, and no significant time-dependent observed in H1299 cells, however, significantly $21 \%$ decreased appeared in H1299 cells at $24 \mathrm{~h}$ (Fig. 1b). 
The effect of daidzein on the proliferation of HELF and H1299 cells were observed. For every 10 times, the concentration of daidzein was increased, cellular viability was increased by an average of $29.47 \%$ (95\%Cl: 22.06, 36.87, $\mathrm{P}<0.001$ ) in HELF cells at the different concentration (from 0 to $1000 \mu \mathrm{M}$ ) of daidzein for 6 hours respectively, and 2.3\% (95\% Cl: $-3.33,-1.29, \mathrm{P}=0.01)$ decrease in H1299 cells (Fig. 1c). And we observed a significantly altered in proliferation, cellular viability increases by an average of $1.83 \%(95 \% \mathrm{Cl}: 1.11,2.55, \mathrm{P}=0.002)$ in HELF cells treated with $10 \mu \mathrm{M}$ daidzein from 0 to $24 \mathrm{~h}$, and a significant time-dependent decrease in $\mathrm{H} 1299$ cells from 0 to $24 \mathrm{~h}$ was not observed, however, $62 \%$ and $49 \%$ were significantly decreased at 12 and 24 hours respectively (Fig. 1d).

\section{The effect of Isoflavone crude extract and Daidzein induced on apoptosis in HELF and H1299 cells}

Apoptotic cells were counted as "late" or "early" apoptotic cells, which are shown respectively in the upper right (UR) and lower right (LR) quadrants of the histograms. The relative apoptosis rate decreased to $76.32 \% \pm 7.86(P<0.05)$ in HELF cells in the experimental group treated with isoflavone crude extract controlled by non-isoflavone crude extract, while non-significantly changed in $\mathrm{H} 1299$ cells in the experiment group which was treated with isoflavone crude extract controlled by non-treatment (Fig. 2a). The relative rate of apoptosis was decreased to $86.13 \% \pm 4.94(P<0.05)$ in HELF cells induced by $10 \mu \mathrm{M}$ daidzein versus the control group without daidzein. Unfortunately, no significant effect of decreased or increased inducing apoptotic in $\mathrm{H} 1299$ cells induced by daidzein (Fig. 2b). Experiments were repeated three times and the resultant data are summarized as the mean of total apoptotic cells (early + late) \pm SD.

\section{Daidzein induced apoptosis-related protein expression in HELF and H1299 cells}

Gene expression microarray detected significantly altered expression profiles between the two groups which were treated with $10 \mu \mathrm{M}$ daidzein and non-treatment in H1299 cells for 6 hours. Microarray results suggest the P53 signaling pathway plays an important role in the apoptosis of $\mathrm{H} 1299$ cells treated with $10 \mu \mathrm{M}$ daidzein compared with the control group. There are 5 genes (Bax, FANCC, TP53, PIGS, CASP9) upregulated and 3 genes (IGF1, FAS, CASP8) down-regulated that were involved in the P53 signaling pathway, and all of these genes were related to apoptosis.

Differences in gene expression between $\mathrm{H} 1299$ cells treatment with $10 \mu \mathrm{M}$ daidzein and $\mathrm{H} 1299$ cells without treatment are encoded in the heat map from low to high. Transcripts that show similar expression patterns are clustered together, as indicated by the colored groups to the right of the heat map (Fig. 3a).

These proteins regulate a wide variety of cellular functions. String 10.0 (http://string-db.org) was used to examine associations among the groups of proteins that were negatively or positively correlated with TP53 (listed in Fig. 3b).

RT-qPCR was performed for the expression of apoptosis-related genes of HELF and H1299 cells with daidzein treatment. As shown in Fig. 4a, the mRNA expression of TP53 and Caspase9 were significantly increased, compared to non-treatment, the mRNA expression level of the Caspase 9 was significantly 
increased to 12.35 times in the HELF, and that was 28.08 times in the $\mathrm{H} 1299$ compared with the control group. At the same time, the expression level of the TP53 was significantly increased to 1.63 times in the HELF, and 2.31 times in the H1299 compared with the group of blank control(Fig. 4a).

As shown in Fig. 4b, Western blot analysis revealed that the levels of caspase9 were increased after the treatment of HELF and $\mathrm{H} 1299$ cells for $6 \mathrm{~h}$ with $10 \mu \mathrm{M}$ daidzein. The relative expression of caspase 9 was significantly decreased to $76 \%$ in HELF cells while non-significantly changed in $\mathrm{H} 1299$ cells. Similar effects on the levels of TP53 was increased 30\% in HELF cells but no increase in H1299 cells (Fig. 4b).

All of these results indicated that daidzein may promote apoptosis of lung cancer cells through the P53 apoptosis pathway. Moreover, the mRNA expression of pro-apoptosis factor TP53 was significantly increased. In conclusion, daidzein induced apoptosis involved in the regulation of multiple apoptosisrelated genes in HELF and H1299 cells.

\section{Verified the absence of p53, then detected the apoptosis in HELF and H1299 cells}

To determine whether the TP53 expression level in the H1299 and HELF cells was associated with their sensitivity to daidzein induced inhibition of proliferation and induction of apoptosis, H1299, and HELF cells were treated with pifithrin-a $(10 \mu \mathrm{M})$ and daidzein, respectively. As shown in Fig. 5a, the relative mRNA expression level of the TP53 was significantly increased to 7.20 times in the HELF, and the expression in the $\mathrm{H} 1299$ was 3.53 times which were treated with $10 \mu \mathrm{M}$ pifithrin-a and $10 \mu \mathrm{M}$ daidzein while $10 \mu \mathrm{M}$ pifithrin-a were controlled. As shown in Fig. 5b, western blot analysis revealed that the relative expression of $\mathrm{P} 53$ was significantly increased by $78 \%$ in $\mathrm{H} 1299$ cells, but the positive result was not observed in HELF cells.

\section{To investigate whether daidzein induced apoptosis was affected by p53 expression in the HELF and H1299 cells}

Both HELF and H1299 cells were treated with $10 \mu \mathrm{M}$ daidzein and $10 \mu \mathrm{M}$ pifithrin-a. It was found that daidzein treatment of HELF and H1299 cells resulted in non-significantly promote or inhibit in HELF cells than $\mathrm{H} 1299$ cells in the numbers of fluorescence-positive cells (Fig. 6).

\section{With PFTa added, the proliferation of HELF and H1299 cells were induced by daidzein}

To verify our hypothesis that the effects on the proliferation of lung cancer cells induced by $10 \mu \mathrm{M}$ daidzein may be produced by P53 pathway genes, the $10 \mu \mathrm{M}$ pifithrin-a was added into HELF and H1299 cells. Pictures were taken when the HELF and $\mathrm{H} 1299$ cells were incubated at $37^{\circ} \mathrm{C}$ with $5 \% \mathrm{CO}_{2}$ for $6 \mathrm{~h}$. HELF and H1299 cells without treatment in the DMEM medium only served as controls (Fig. 7a, d). The proliferation of HELF and H1299 cells with PFTa were more obvious than the control group (Fig. 7b, e). Added PFTa and daidzein, the proliferation of HELF and H1299 cells were more obvious than the control group but not more obvious than PFTa (Fig. 7c, f). The results of cell count displayed that the proliferation was significantly promoted when PFTa was added, $10 \%$ and $11 \%$ were promoted in HELF 
and $\mathrm{H} 1299$ cells in the group of PFTa; $12 \%$ was significant promoted in the groups of PFTa and DD in HELF cells (Fig. 7g).

\section{Discussion}

The results of the study showed that The effects of $100 \mathrm{~g} / \mathrm{L}$ isoflavone crude extract and $10 \mathrm{M}$ daidzein on the proliferation of lung cancer cells were both concentration and time-dependent. These results were in agreement with various studies that demonstrated the apoptosis of cancer cells would be increased by isoflavone in vitro experiments $(16,17)$. The proliferation affected by isoflavone crude extract or daidzein was also found in the same pattern through CCK8 assay. Flow cytometry assay showed that isoflavones crude extract and daidzein could affect apoptosis in HELF cells, however, no significant inhibition on apoptosis in $\mathrm{H} 1299$ cells was observed. The results matched the data obtained by microarray; the consistencies observed are likely due to the sensitivity of different methods or experimental errors.

Apoptosis is primarily executed by a family of proteases known as the caspases (cysteinyl, aspartatespecific proteases)(18). The key event in apoptosis is the activation of caspases through two major cascades: caspase8 and caspase 9 are the principal enzymes in the extrinsic apoptotic pathway and the intrinsic apoptotic pathway, respectively(19). Combined with the results of this study, we speculated that the gene expression of caspase 9 is associated with isoflavone induced apoptosis of lung cancer cells.

The results showed that the mRNA levels were significantly increased in HELF and H1299 cells treated with daidzein by RT-qPCR. The expression mRNA of caspase9 in $\mathrm{H} 1299$ and HELF cells was increased in the daidzein group versus to control group. The results of Western blot showed that the protein expression of caspase 9 in HELF cells treated with daidzein was significantly different from that in $\mathrm{H} 1299$ cells. It is well known that there are differences in the expression levels of mRNA and protein.

As mentioned earlier, P53 essentially protects the genome from mutation and/or alterations. DNA damage led to stable P53 protein, which activates other downstream genes or factors to cause cell cycle arrest or DNA repair(20). The tumor suppressor P53 is a transcription factor, upon DNA damage, which is activated to induce sequence-specific target genes involved in either cancer cell growth arrest or apoptosis(21). Regarding the apoptotic function of the intrinsic pathway, P53 seems to play a pivotal role because it modulates both pro-survival and pro-apoptotic Bcl-2 family members(22).

In normal cells, P53 is expressed at low levels, but in cancer cells, the function of P53 is regulated by its specific target murine double minute 2 (MDM2) by a process of ubiquitination(23). When P53 is expressed in cancer cells, it has to be phosphorylated to induce expressions of the downstream of TP53 genes such as P21 and Bax. Cellular apoptosis was induced by the P53-independent pathway without p53 expression(24). The TP53 gene is an essential component of the pathway leading to two different critical functions: G1 growth arrest and apoptosis(25). 
The result of RT-qPCR showed that the mRNA expression of TP53 was significantly increased in HELF and $\mathrm{H} 1299$ cells treated with daidzein. The recognition of the expression of P53 in lung cancer by the Western blot experiment was regarded as apoptosis. These results support that daidzein has a capability of inducing apoptosis in lung tumor cells, resulting in inhibition of tumor growth. Therefore, we speculate that the effect of apoptosis induced by daidzein in HELF and H1299 cells through the mRNA level of P53.

Pifithrin-a, a pharmacological TP53 inhibitor, was used to suppress the expression of TP53. The mRNA expression of TP53 was increased in HELF and H1299 cells in both two groups. The surprising point is the protein expression of TP53 significantly increased in $\mathrm{H} 1299$ cells induced by daidzein, while it does not appear a significantly suppress proliferation in HELF cells as expected. This indicates that TP53 plays an important role in the process of daidzein against tumor cells.

\section{Conclusions}

In summary, the present study indicated that daidzein affects the proliferation of $\mathrm{H} 1299$ cells induced by daidzein. Therefore, we confirmed that daidzein plays a pivotal role in promoting apoptosis in lung adenocarcinoma cells, and the mechanism involved in the expression of caspase9 and the P53 gene in the apoptotic pathway.

\section{Abbreviations}

CCK8: Cell counting kit-8; DD: Daidzein; HELF: Duman embryonic lung fibroblast cells; H1299: Human lung adenocarcinoma cells; PFTa: pifithrin-a;

\section{Declarations}

\section{Acknowledgments}

The authors wish to acknowledge professor Shaoxin Huang of Jiujiang university for his help in interpreting the significance of the results in this study.

\section{Funding}

The authors acknowledge funding from the Natural Natural Science Foundation of China (No. 81660541 and No.8136044 ), the Natural Science Foundation of Jiangxi (No.20181BAB205067), and the China Postdoctoral Science Foundation (No.2019M652334).

\section{Availability of data and materials}

All data generated or analyzed during this study were included in this published article.

\section{Authors' contributions}


Shaoxin Huang conceived and designed the study. Xiaobo Wang, Xiaowei Xiong, Ouyang Jin, and Chengquan Cheng performed the experiments. You Peng provides isoflavone crude extract. Xiaobo Wang analyzed the results and wrote the paper. Shaoxin Huang, Denggang Fu, You Peng, and Xin Wang reviewed and edited the manuscript. All authors read and approved the manuscript.

\section{Ethics approval and consent to participate}

Not applicable

\section{Patient consent for publication}

Not applicable

\section{Competing interests}

The authors declare that they have no competing interests.

\section{References}

1. Baena RR, Salinas HP. Cancer chemoprevention by dietary phytochemicals: Epidemiological evidence. MATURITAS. 2016; 94: 13-19.

2. Wu SH, Liu Z. Soy Food Consumption and Lung Cancer Risk: A Meta-Analysis Using a Common Measure Across Studies. Nutrition and Cancer. 2013; 65: 625-32.

3. Baena RR, Salinas HP. Cancer chemoprevention by dietary phytochemicals: Epidemiological evidence. MATURITAS. 2016; 94: 13-19.

4. Yang G, Shu XO, Chow W, et al. Soy Food Intake and Risk of Lung Cancer: Evidence From the Shanghai Women's Health Study and a Meta-Analysis. AM J EPIDEMIOL. 2012; 176: 846-55.

5. Yang G, Shu XO, Li HL, et al. Prediagnosis soy food consumption and lung cancer survival in women. J CLIN ONCOL. 2013; 31: 1548-53.

6. Wakai K, Ohno Y, Genka K, et al. Risk modification in lung cancer by a dietary intake of preserved foods and soyfoods: findings from a case-control study in Okinawa, Japan. LUNG CANCER. 1999; 25: $147-59$.

7. Hooper L, Ryder JJ, Kurzer MS, et al. Effects of soy protein and isoflavones on circulating hormone concentrations in pre- and post-menopausal women: a systematic review and meta-analysis. HUM REPROD UPDATE. 2009; 15: 423-40.

8. Peng Y, Shi Y, Zhang H, et al. Anti-inflammatory and anti-oxidative activities of daidzein and its sulfonic acid ester derivatives. J FUNCT FOODS. 2017; 35: 635-40.

9. Cassidy A, Albertazzi P, Nielsen IL, et al. Critical review of health effects of soyabean phytooestrogens in post-menopausal women. P NUTR SOC. 2006; 65: 76-92.

10. Applegate C, Rowles J, Ranard K, et al. Soy Consumption and the Risk of Prostate Cancer: An Updated Systematic Review and Meta-Analysis. NUTRIENTS. 2018; 10: 40. 
11. Zhang B, Chen X, Zhou Q, et al. Human gene expression microarray analysis of the HPV 6bE7-HaCaT stable cell line. GENE. 2018; 657: 60-68.

12. Sharafi $H$, Rahimi R. The effect of resistance exercise on $p 53$, caspase-9, and caspase-3 in trained and untrained men. J STRENGTH COND RES. 2012; 26: 1142-48.

13. Katiyar SK, Meeran SM, Katiyar N, et al. p53 cooperates berberine-induced growth inhibition and apoptosis of non-small cell human lung cancer cells in vitro and tumor xenograft growth in vivo. MOL CARCINOGEN. 2009; 48: 24-37.

14. Kim B, Srivastava SK, Kim SH. Caspase-9 as a therapeutic target for treating cancer. Expert Opin Ther Targets. 2015; 19: 113-27.

15. Youl P, Ze-Yuan D, Zhi-Gangl Y, et al. Extraction of soybean isoflavone by microwave radiation without solvent and its mechanism. GUIHAIA. 2011: 266-69.

16. Romagnolo DF, Selmin OI. Flavonoids and Cancer Prevention: A Review of the Evidence. Journal of Nutrition in Gerontology and. 2012; 31: 206-38.

17. Li Z, Zhao Y, Wu X, et al. Barbigerone, a Natural Isoflavone, Induces Apoptosis in Murine Lung-Cancer Cells via the Mitochondrial Apoptotic Pathway. CELL PHYSIOL BIOCHEM. 2009; 24: 95-104.

18. Li J, Yuan J. Caspases in apoptosis and beyond. ONCOGENE. 2008; 27: 6194-206.

19. Thornberry NA. Caspases: Enemies Within. SCIENCE. 1998; 281: 1312-16.

20. Rasmussen MA, Holst BR, Tümer Z, et al. Transient p53 Suppression Increases Reprogramming of Human Fibroblasts without Affecting Apoptosis and DNA Damage. STEM CELL REP. 2014; 3: 404-13.

21. Vousden KH, Lane DP. p53 in health and disease. NAT REV MOL CELL BIO. 2007; 8: 275-83.

22. Pistritto $G$, Trisciuoglio $D$, Ceci $C$, et al. Apoptosis as anticancer mechanism: function and dysfunction of its modulators and targeted therapeutic strategies. Aging (Albany NY). 2016; 8: 60319.

23. Gadepalli VS, Deb SP, Deb S, et al. Lung cancer stem cells, p53 mutations and MDM2. Subcell Biochem. 2014; 85: 359-70.

24. Choi JH, Ahn KS, Kim J, et al. Enhanced induction of Bax gene expression in $\mathrm{H} 460$ and $\mathrm{H} 1299$ cells with the combined treatment of cisplatin and adenovirus mediated wt-p53 gene transfer. EXP MOL MED. 2000; 32: 23-28.

25. Levine AJ. p53, the cellular gatekeeper for growth and division. CELL. 1997; 88: 323-31.

\section{Figures}



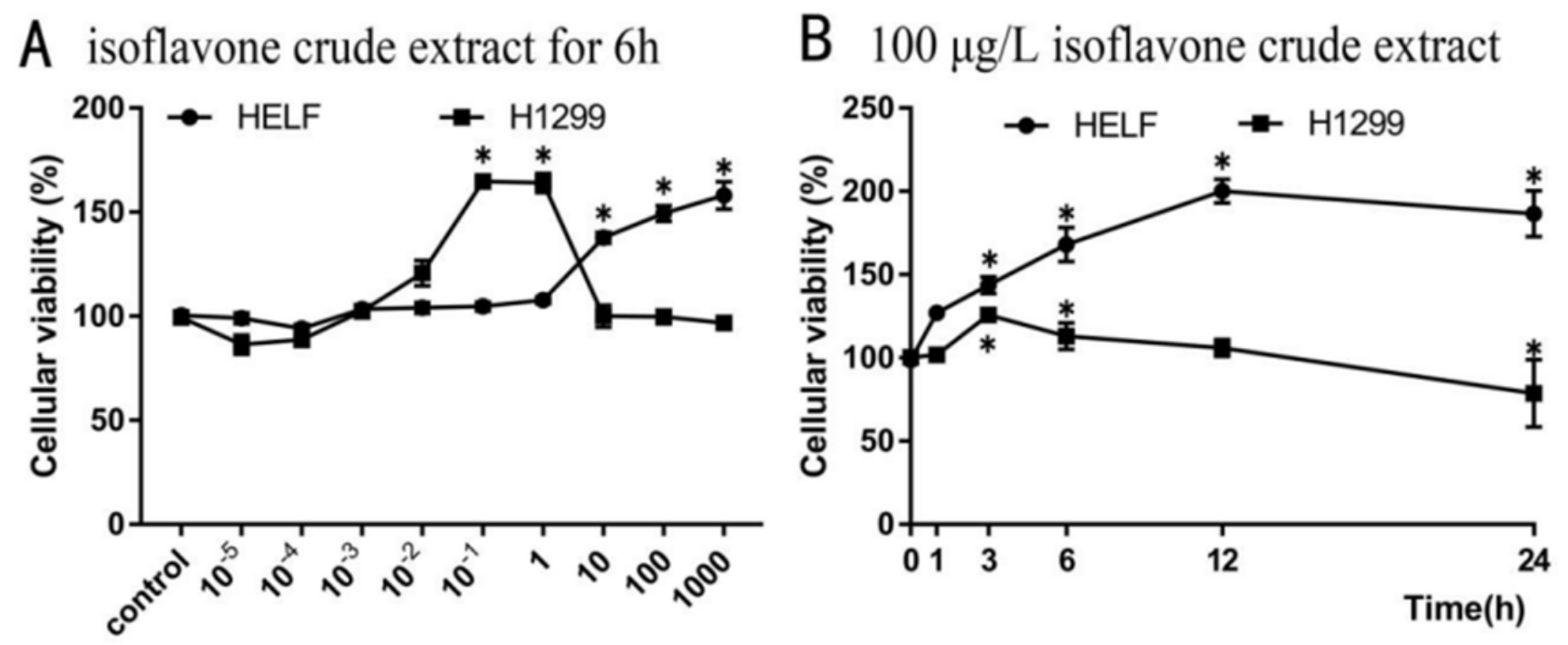

Concentration $(\mu \mathrm{M})$

C daidzein for $6 \mathrm{~h}$

D $10 \mu \mathrm{M}$ daidzein

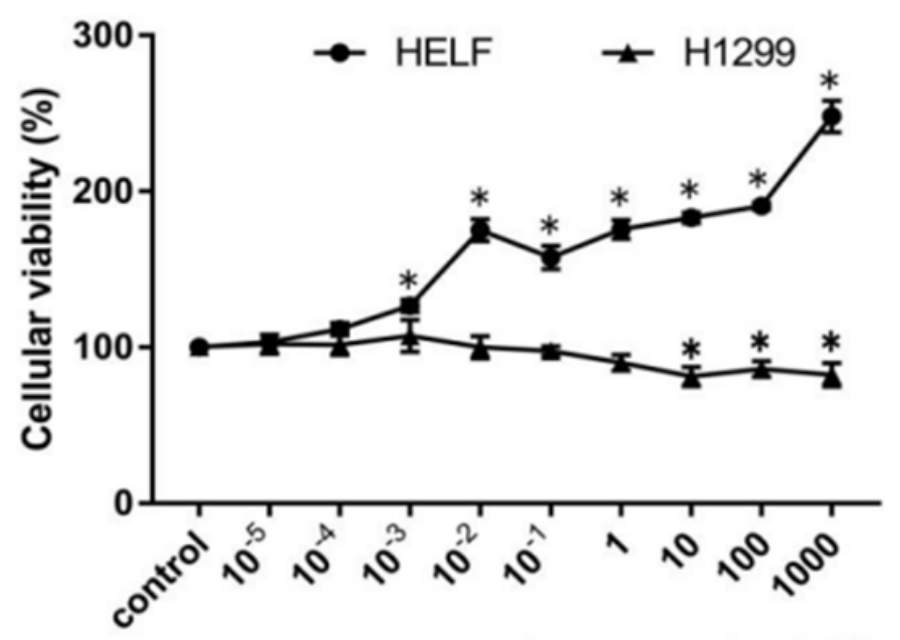

Concentration $(\mu \mathrm{M})$

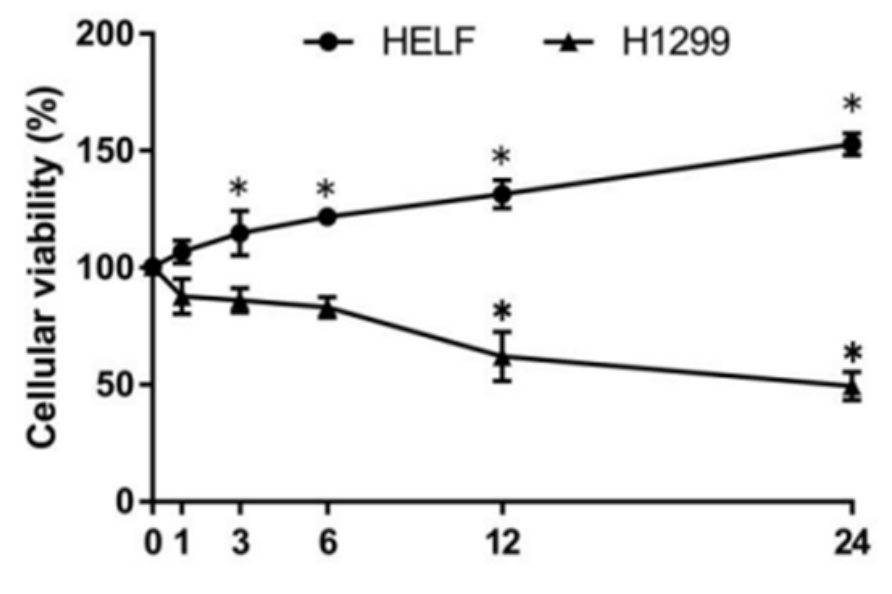

Time(h)

Figure 1

Effects of daidzein on the proliferation of HELF and H1299 cells by the CCK8 assay. a Cells were treated with isoflavone crude extracts at different concentrations for 6 h. b $100 \mathrm{~g} / \mathrm{L}$ isoflavone crude extracts were treated for a different time. c Cells were treated with daidzein at different concentrations for 6 hours. d Cells were exposed to $10 \mu \mathrm{M}$ daidzein for a different time. 

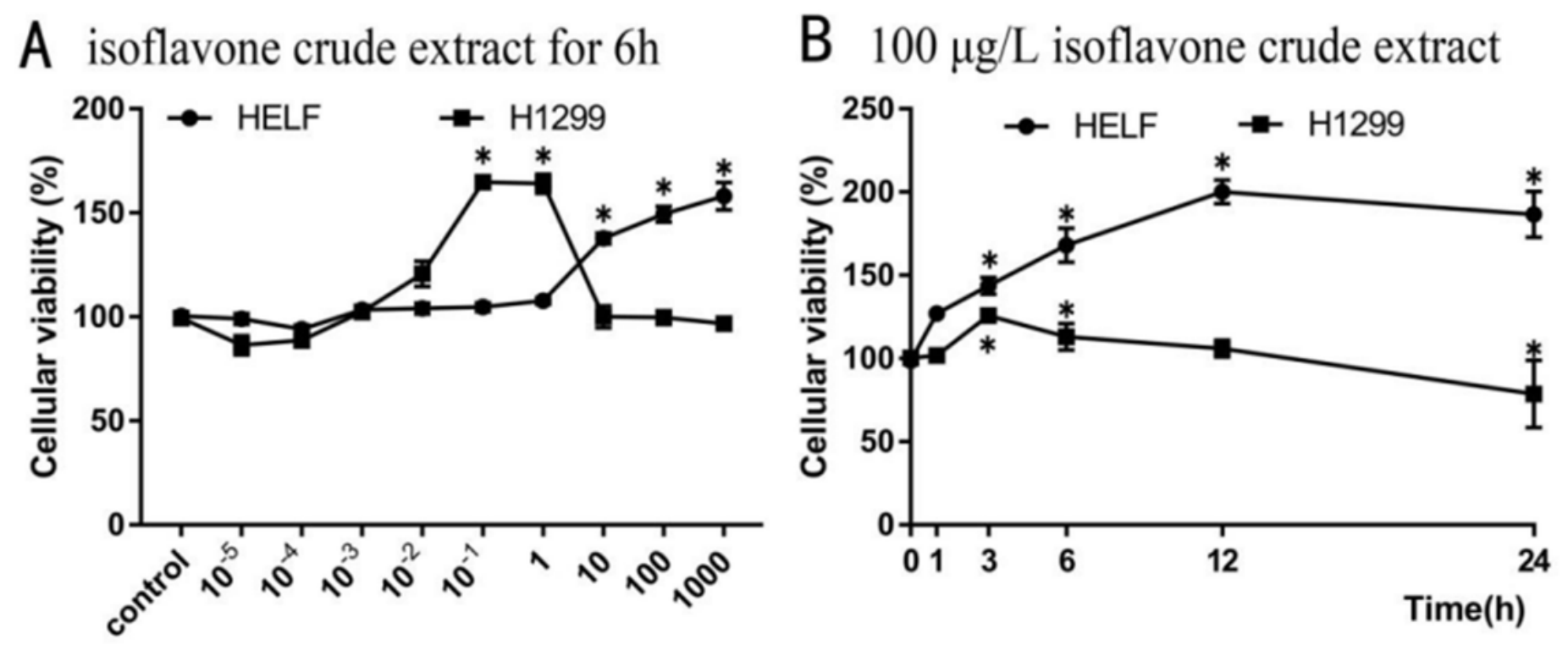

Concentration $(\mu \mathrm{M})$

C daidzein for $6 \mathrm{~h}$

D $10 \mu \mathrm{M}$ daidzein

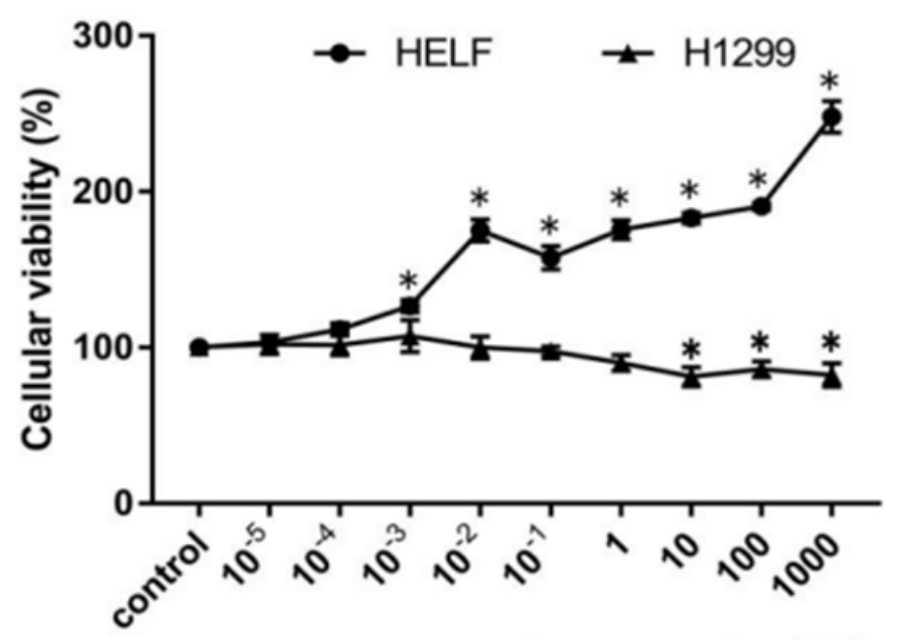

Concentration $(\mu \mathrm{M})$

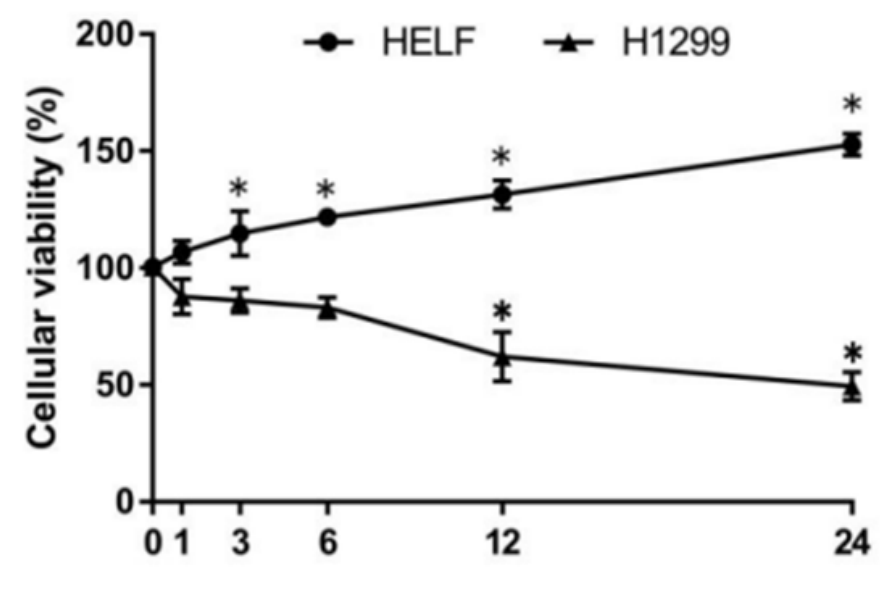

Time(h)

Figure 1

Effects of daidzein on the proliferation of HELF and H1299 cells by the CCK8 assay. a Cells were treated with isoflavone crude extracts at different concentrations for 6 h. b $100 \mathrm{~g} / \mathrm{L}$ isoflavone crude extracts were treated for a different time. c Cells were treated with daidzein at different concentrations for 6 hours. d Cells were exposed to $10 \mu \mathrm{M}$ daidzein for a different time. 

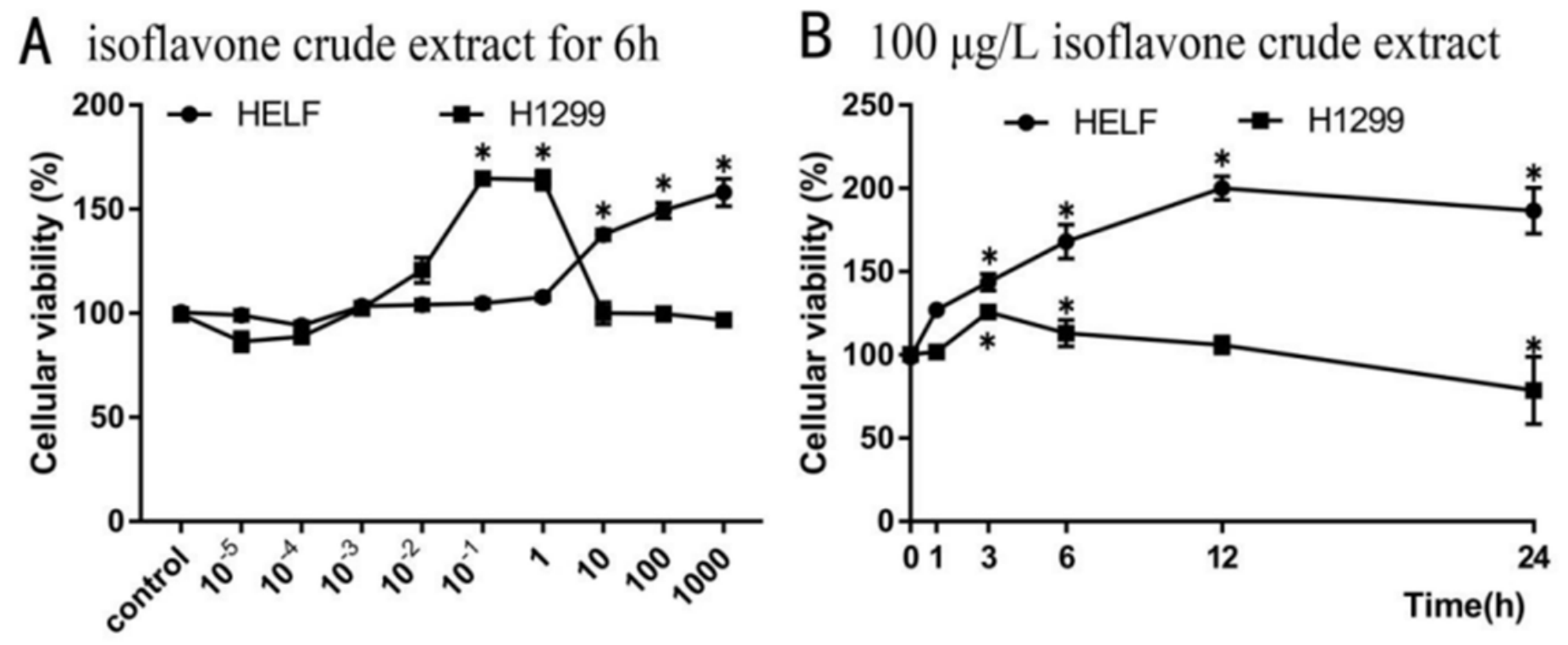

\section{Concentration $(\mu \mathrm{M})$}

C daidzein for $6 \mathrm{~h}$

D $10 \mu \mathrm{M}$ daidzein

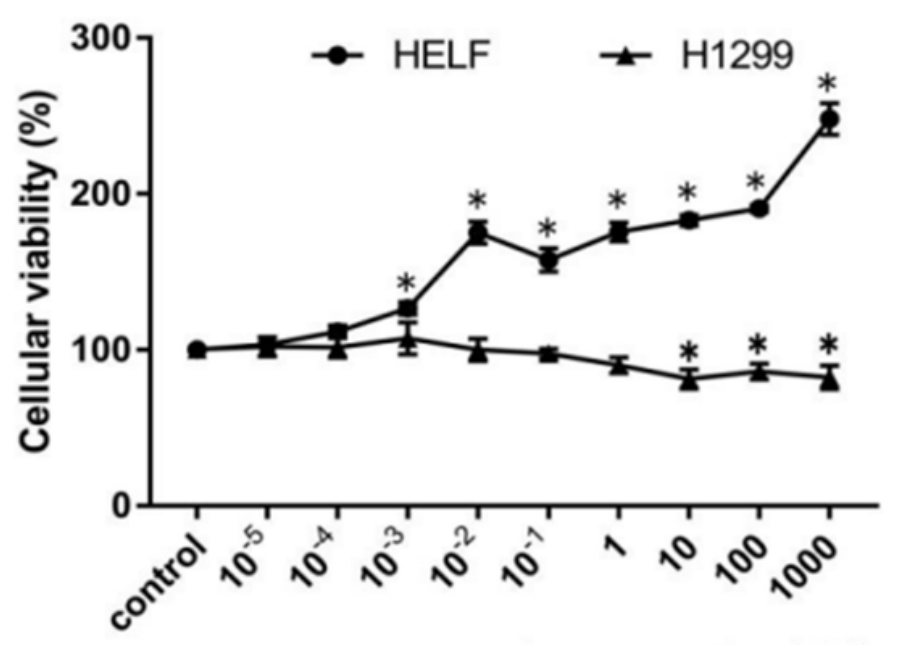

Concentration $(\mu \mathrm{M})$

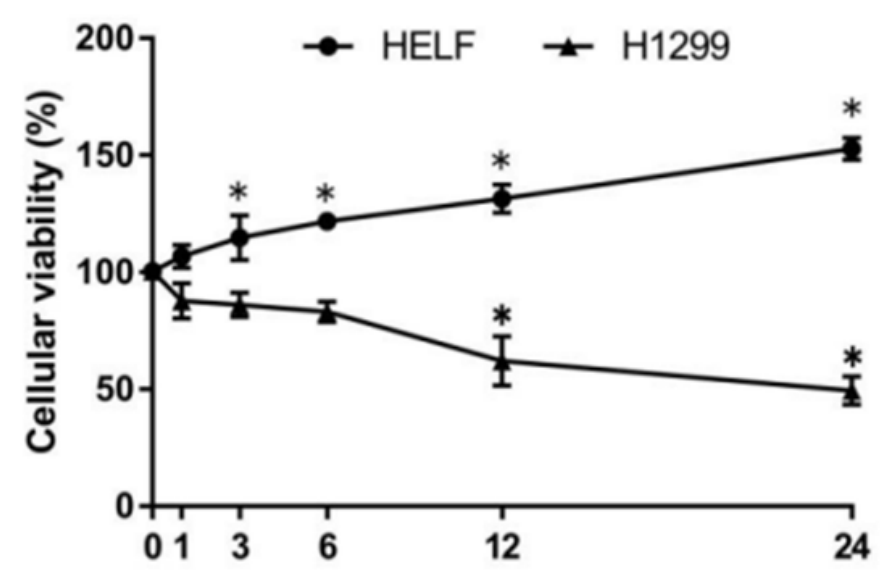

Time(h)

Figure 1

Effects of daidzein on the proliferation of HELF and H1299 cells by the CCK8 assay. a Cells were treated with isoflavone crude extracts at different concentrations for 6 h. b $100 \mathrm{~g} / \mathrm{L}$ isoflavone crude extracts were treated for a different time. c Cells were treated with daidzein at different concentrations for 6 hours. d Cells were exposed to $10 \mu \mathrm{M}$ daidzein for a different time. 

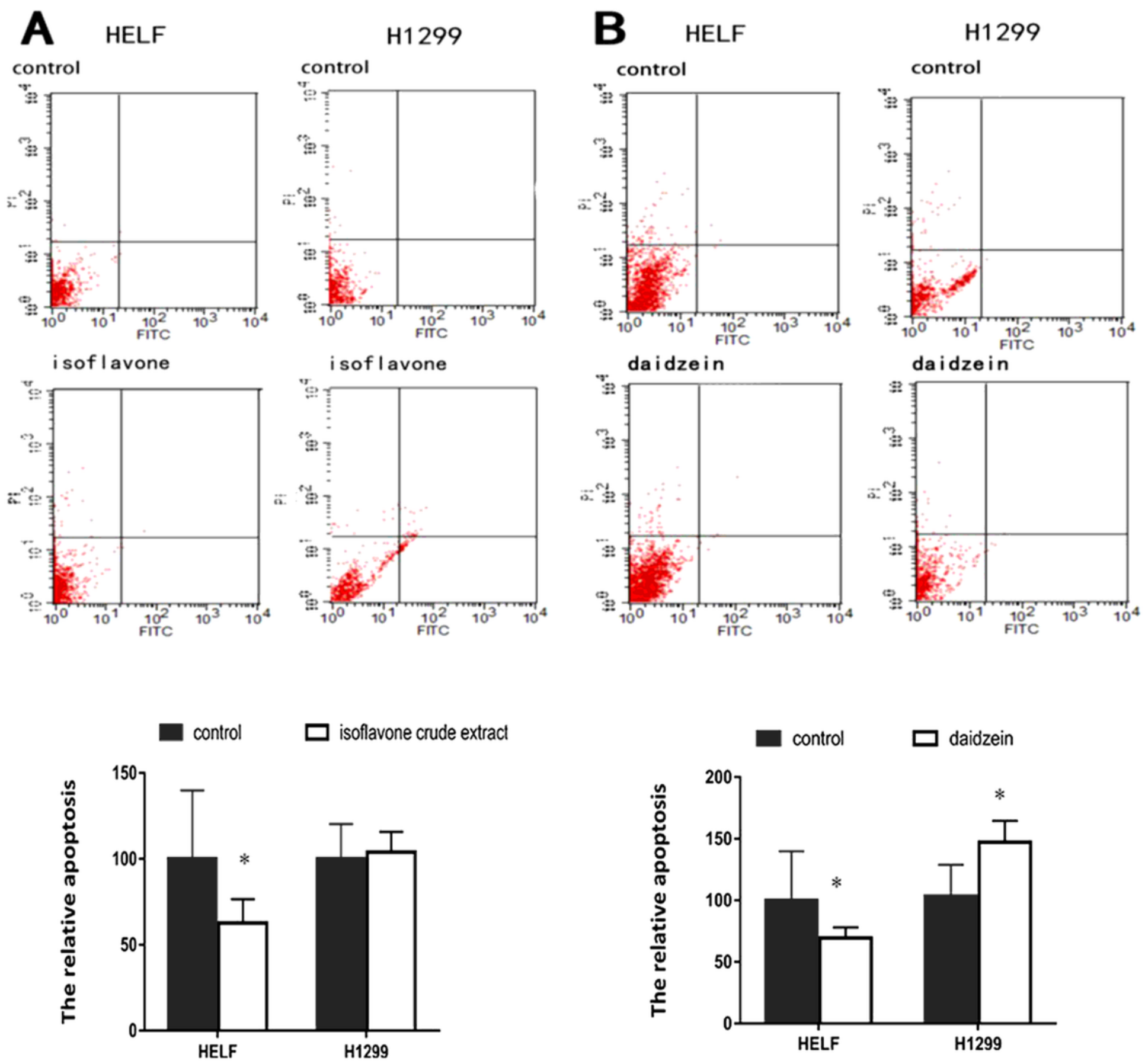

Figure 2

Detection of apoptosis by flow cytometry. a The relative apoptosis rate in HELF and H1299 cells induced by $100 \mu \mathrm{g} / \mathrm{L}$ isoflavone crude extract for 6 hours. b The relative apoptosis rate in HELF and H1299 cells induced by $10 \mu \mathrm{M}$ daidzein for 6 hours. 

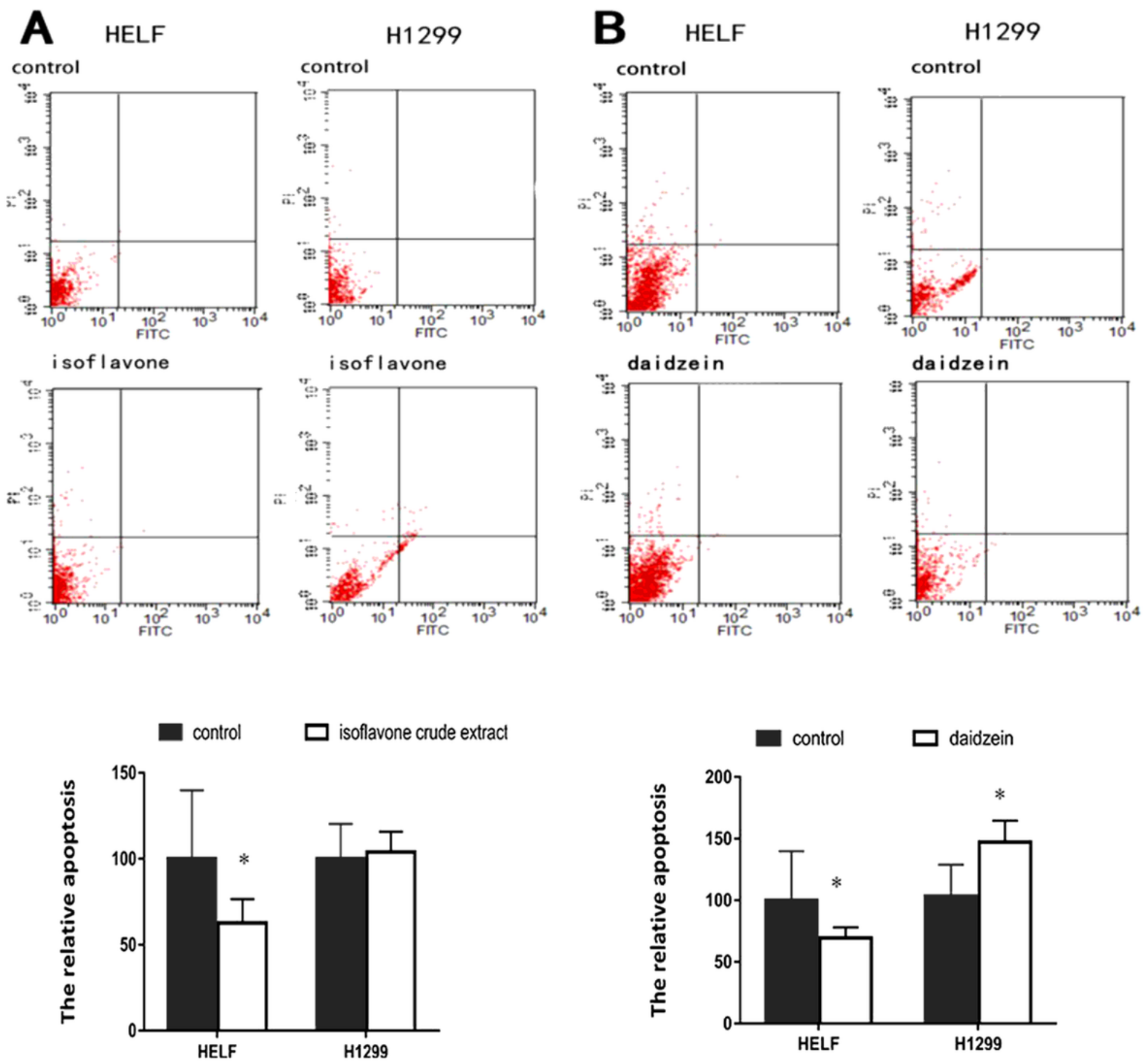

\section{Figure 2}

Detection of apoptosis by flow cytometry. a The relative apoptosis rate in HELF and H1299 cells induced by $100 \mu \mathrm{g} / \mathrm{L}$ isoflavone crude extract for 6 hours. b The relative apoptosis rate in HELF and H1299 cells induced by $10 \mu \mathrm{M}$ daidzein for 6 hours. 

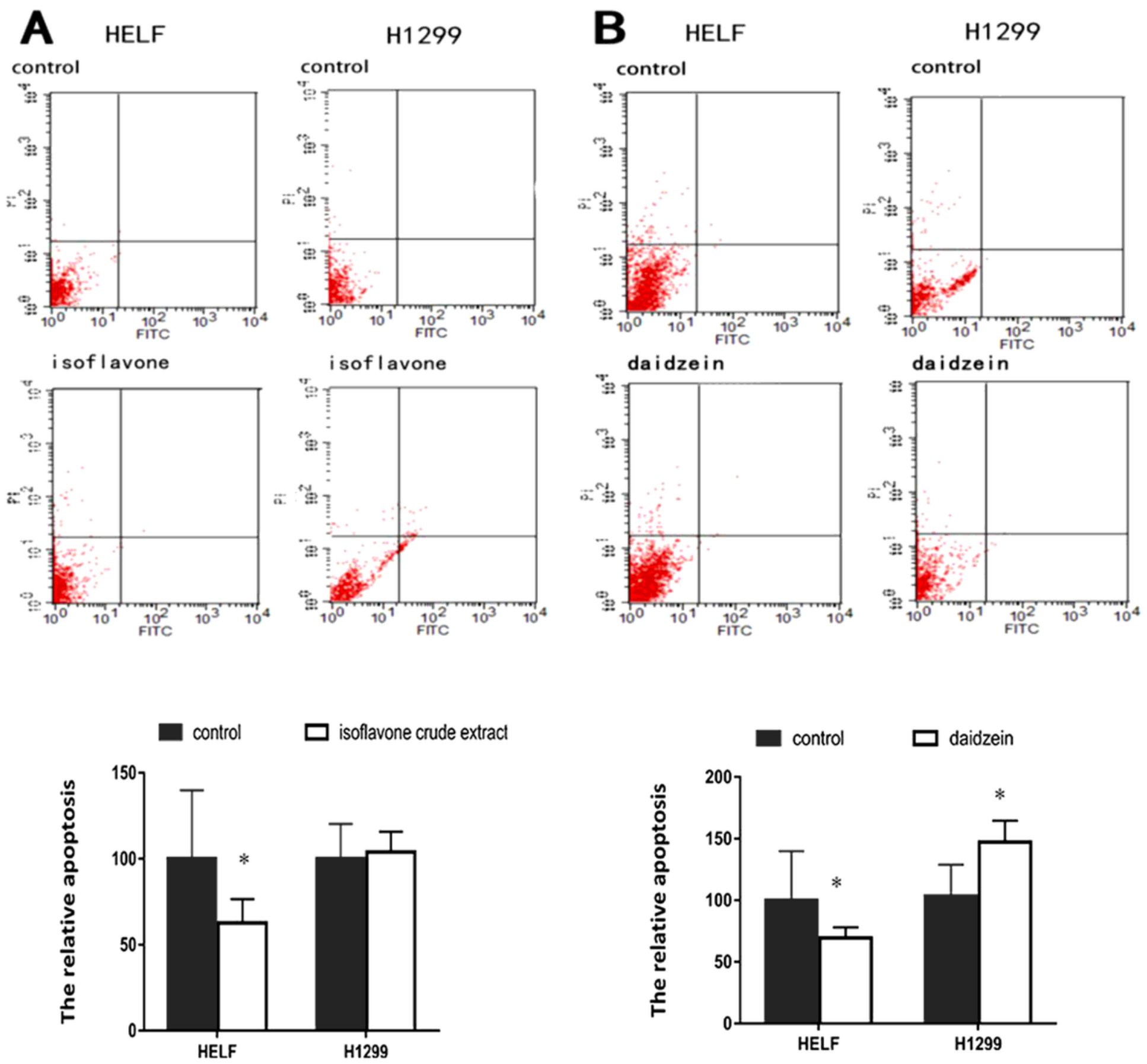

\section{Figure 2}

Detection of apoptosis by flow cytometry. a The relative apoptosis rate in HELF and H1299 cells induced by $100 \mu \mathrm{g} / \mathrm{L}$ isoflavone crude extract for 6 hours. b The relative apoptosis rate in HELF and H1299 cells induced by $10 \mu \mathrm{M}$ daidzein for 6 hours. 


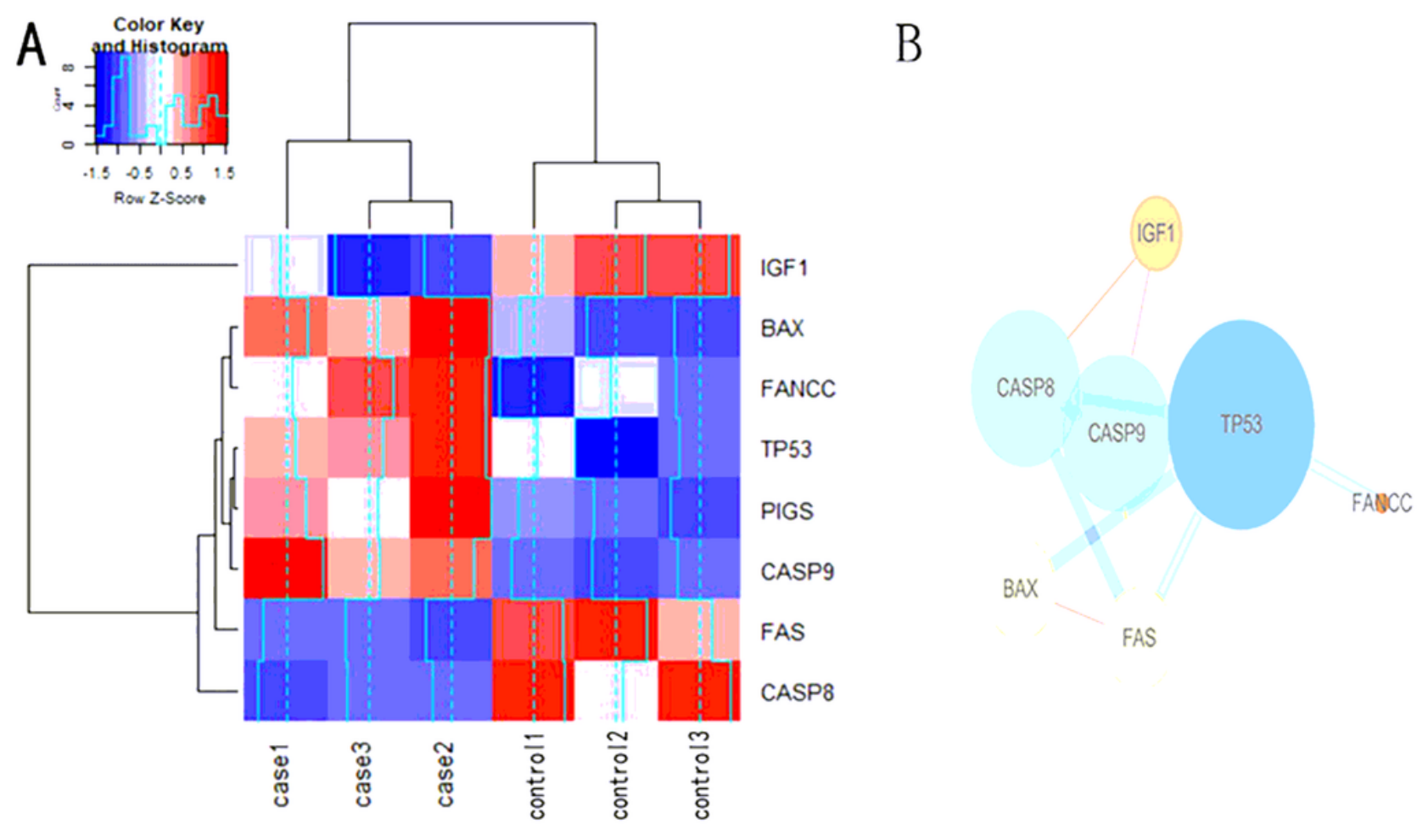

Figure 3

The results of microarray in H1299 cells treatment with $10 \mu \mathrm{M}$ daidzein for 6 hours. a The heat map of up and down-regulation expression level genes of P53 pathway genes in H1299 cells induced by daidzein. b String analysis was performed on proteins identified.

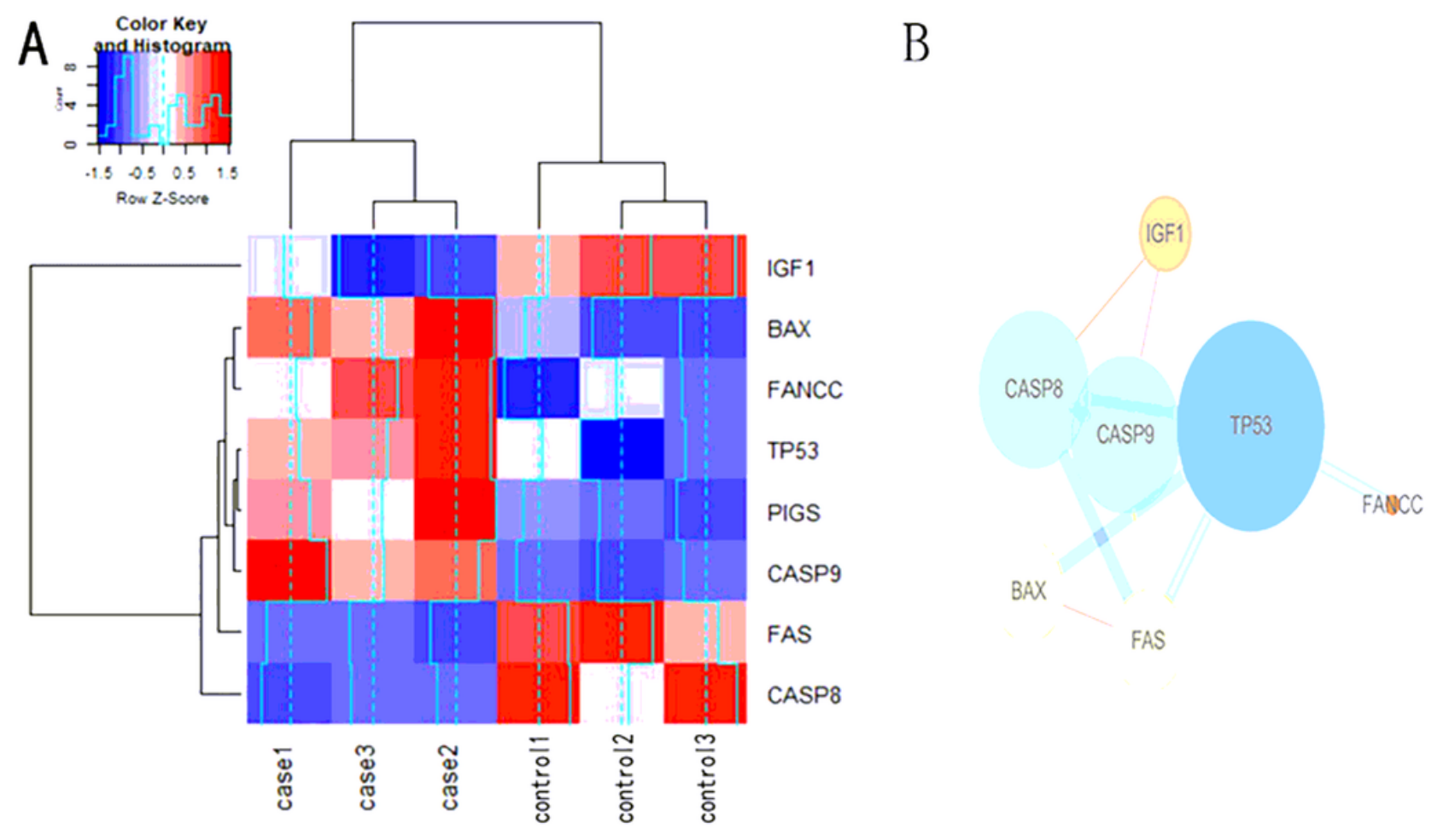

Figure 3 
The results of microarray in $\mathrm{H} 1299$ cells treatment with $10 \mu \mathrm{M}$ daidzein for 6 hours. a The heat map of up and down-regulation expression level genes of P53 pathway genes in H1299 cells induced by daidzein. b String analysis was performed on proteins identified.

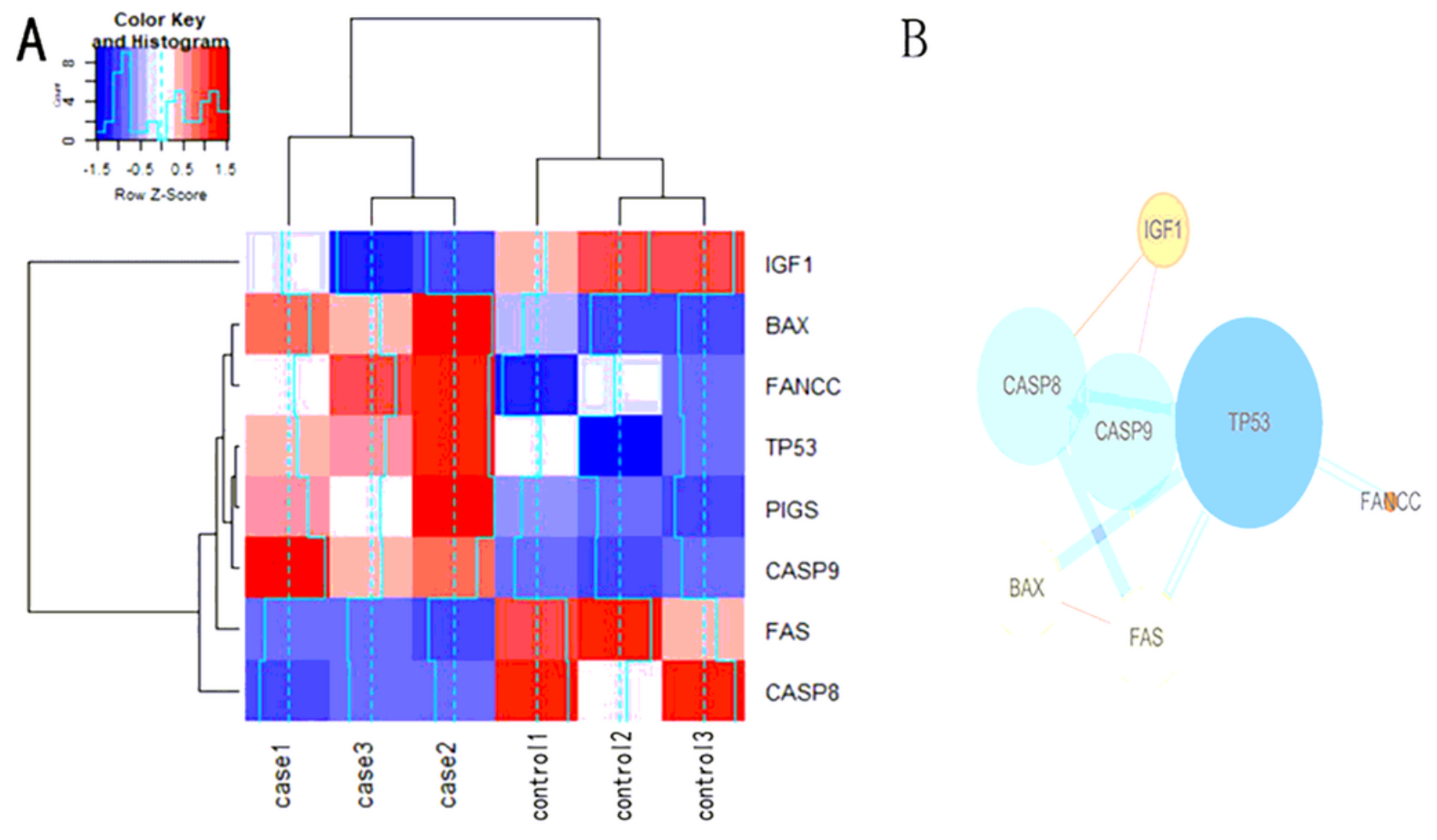

Figure 3

The results of microarray in $\mathrm{H} 1299$ cells treatment with $10 \mu \mathrm{M}$ daidzein for 6 hours. a The heat map of up and down-regulation expression level genes of P53 pathway genes in H1299 cells induced by daidzein. b String analysis was performed on proteins identified. 


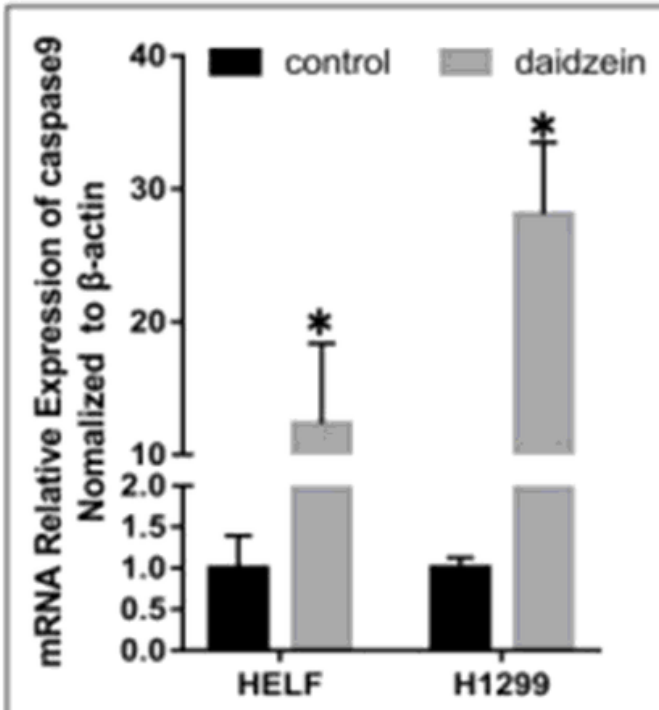

B

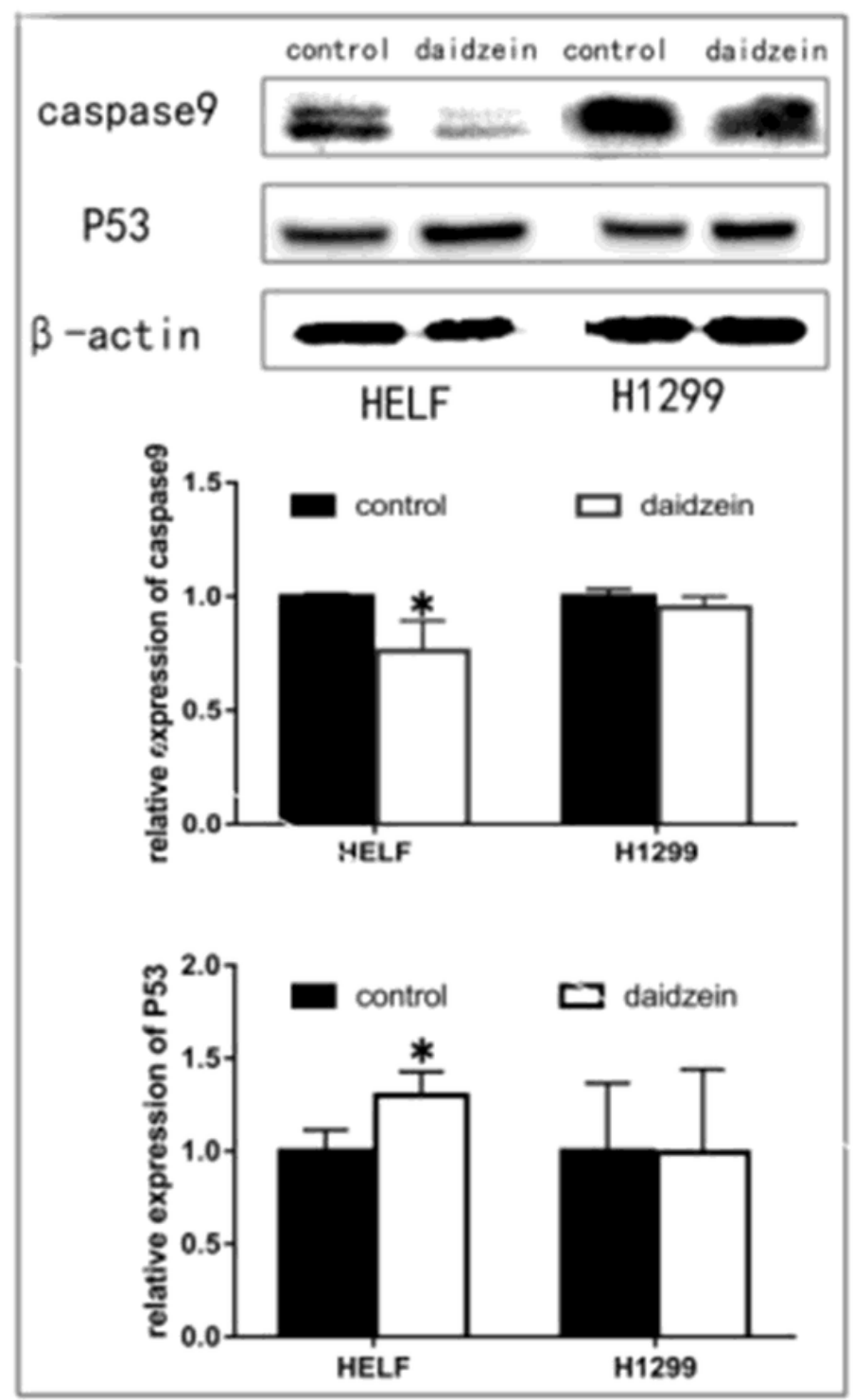

Figure 4

The relative expression of Caspase 9 and TP53 in HELF and H1299 cells treatment with $10 \mu \mathrm{M}$ daidzein for 6 hours. a The mRNA expression of Caspase9 and TP53. bThe protein expression of TP53 and Caspase9. $\beta$-actin was used to normalize protein loading. ${ }^{*} \mathrm{P}<0.05$ 


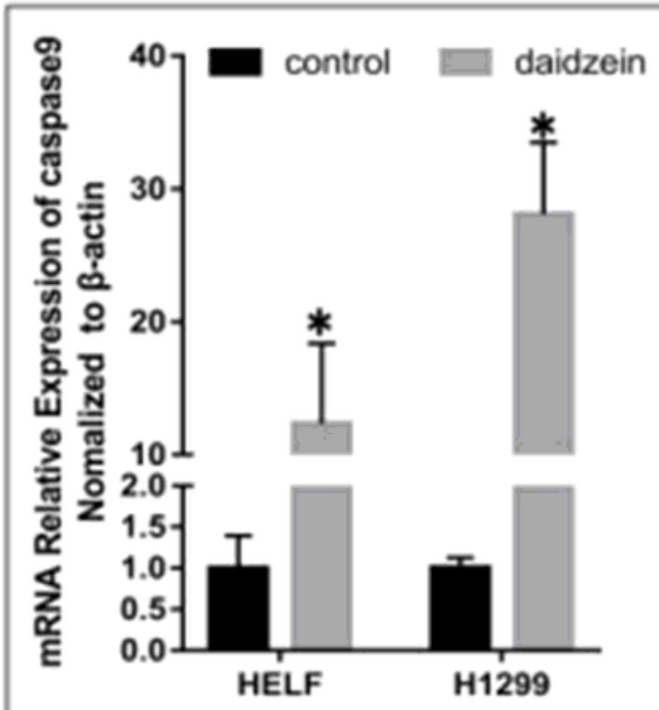

B

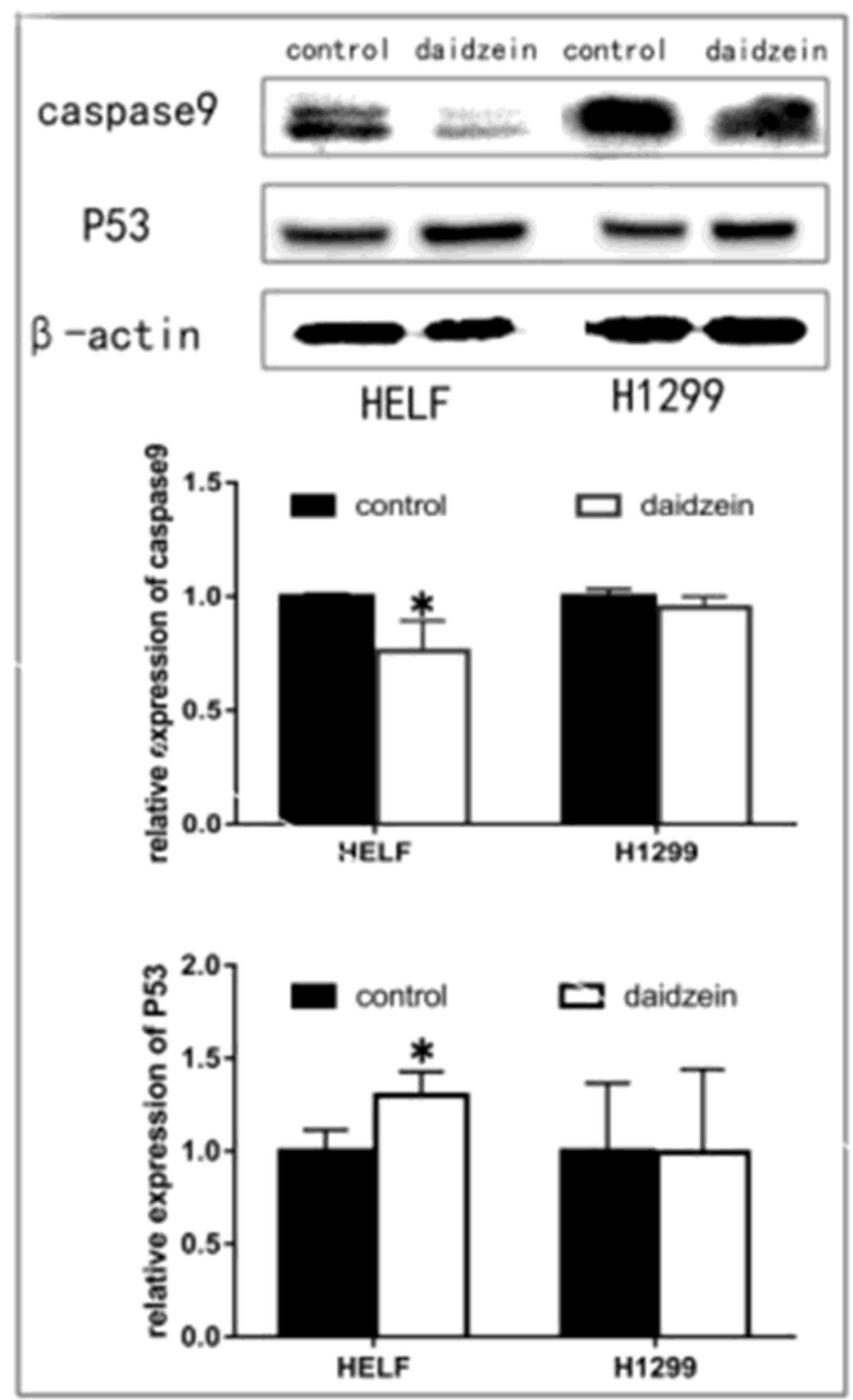

Figure 4

The relative expression of Caspase 9 and TP53 in HELF and H1299 cells treatment with $10 \mu \mathrm{M}$ daidzein for 6 hours. a The mRNA expression of Caspase9 and TP53. bThe protein expression of TP53 and Caspase9. $\beta$-actin was used to normalize protein loading. ${ }^{*} \mathrm{P}<0.05$ 


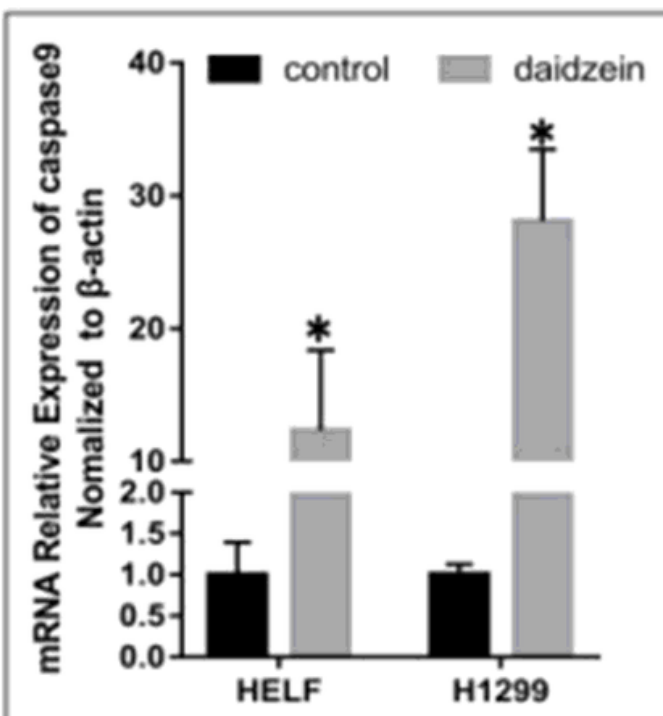

B

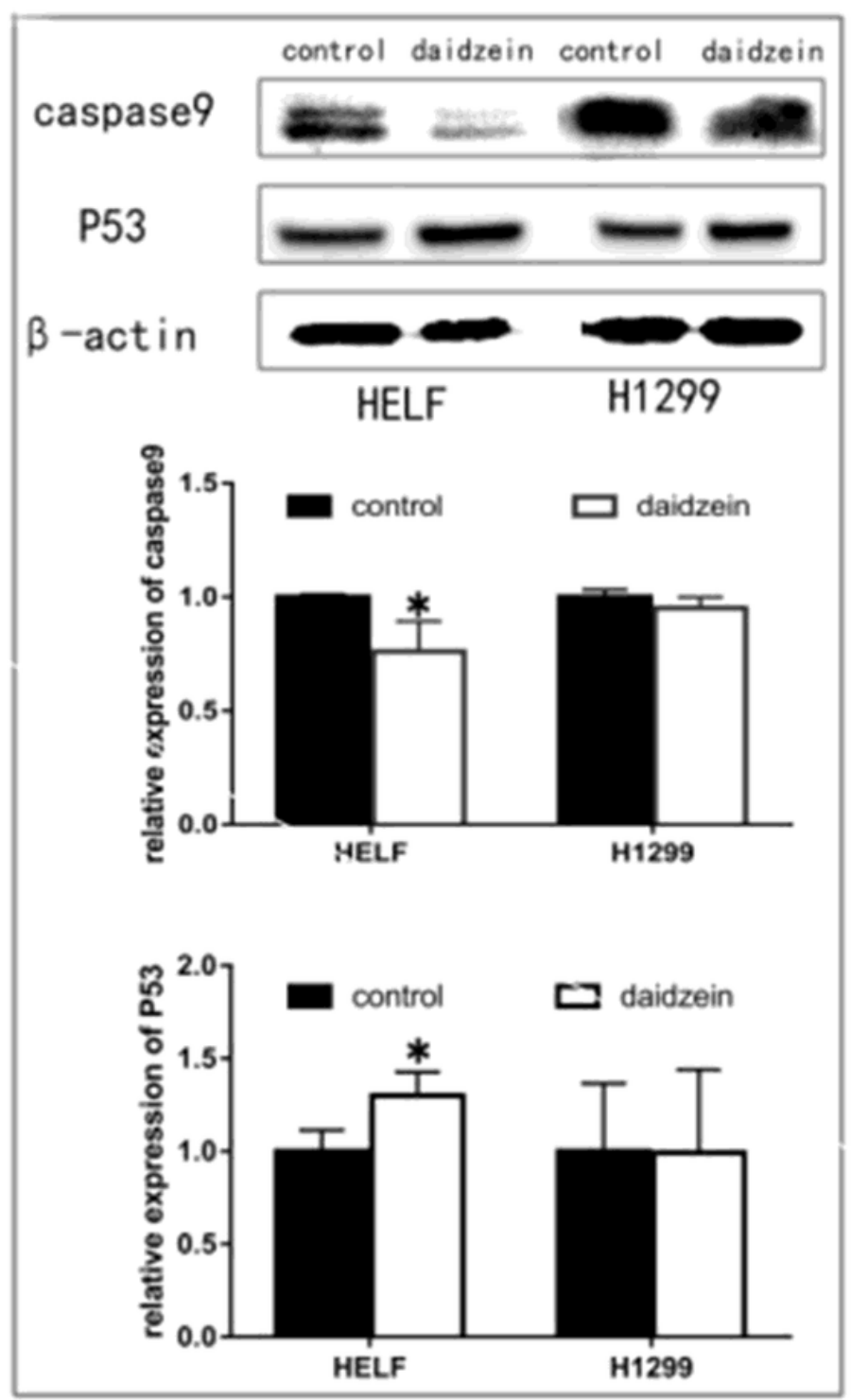

Figure 4

The relative expression of Caspase 9 and TP53 in HELF and H1299 cells treatment with $10 \mu \mathrm{M}$ daidzein for 6 hours. a The mRNA expression of Caspase9 and TP53. bThe protein expression of TP53 and Caspase9. $\beta$-actin was used to normalize protein loading. ${ }^{*} \mathrm{P}<0.05$ 


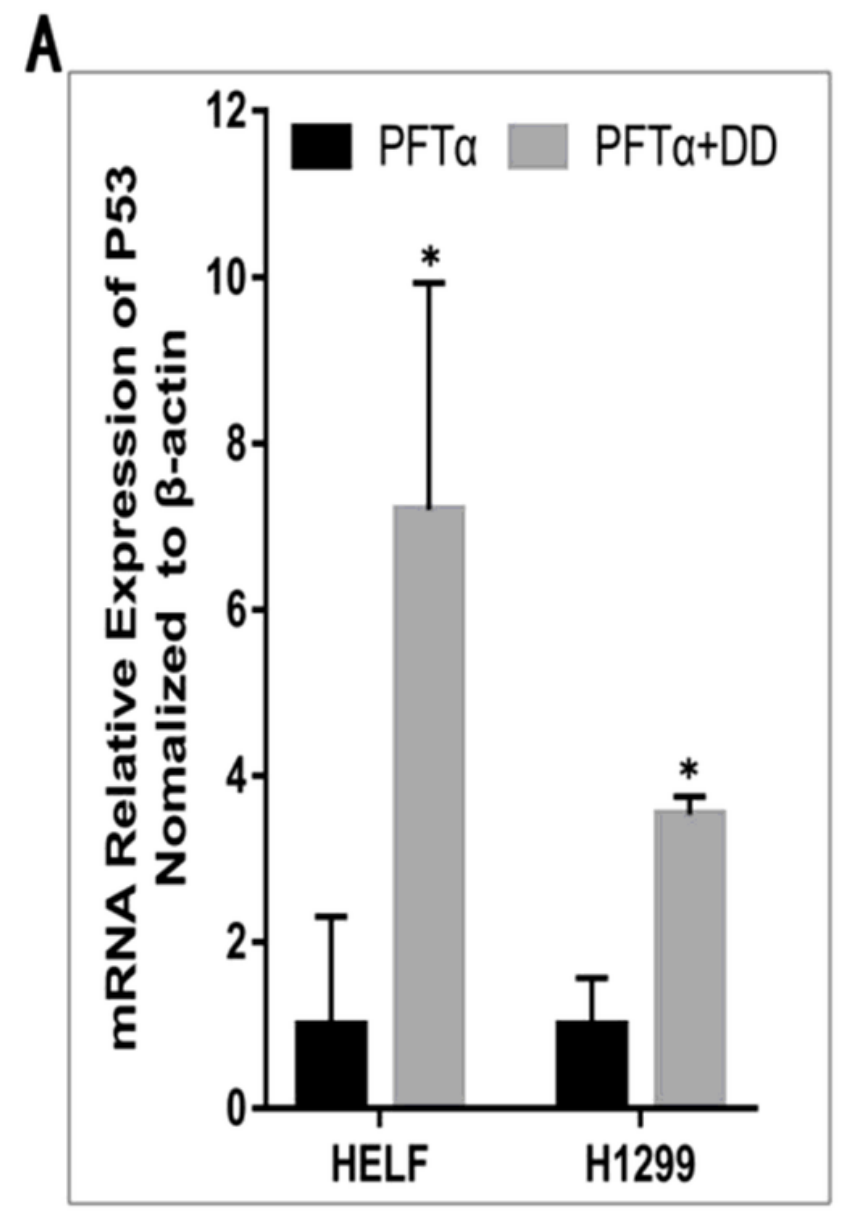

B

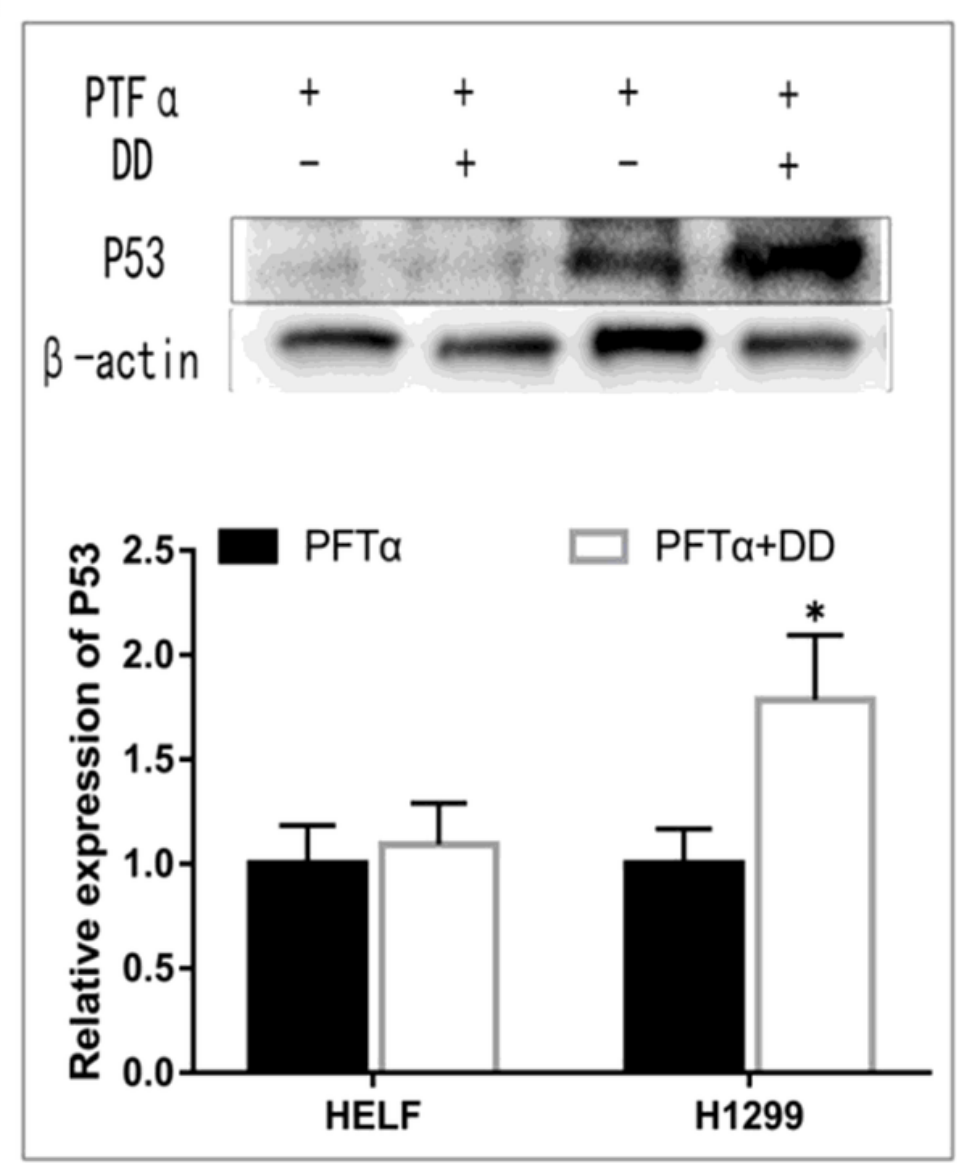

Figure 5

Daidzein-induced apoptosis is associated with increased P53 levels in HELF and H1299 cells. a mRNA expression of TP53. b The protein expression of P53. Error bars represent \pm SE and *P $<0.05$. 


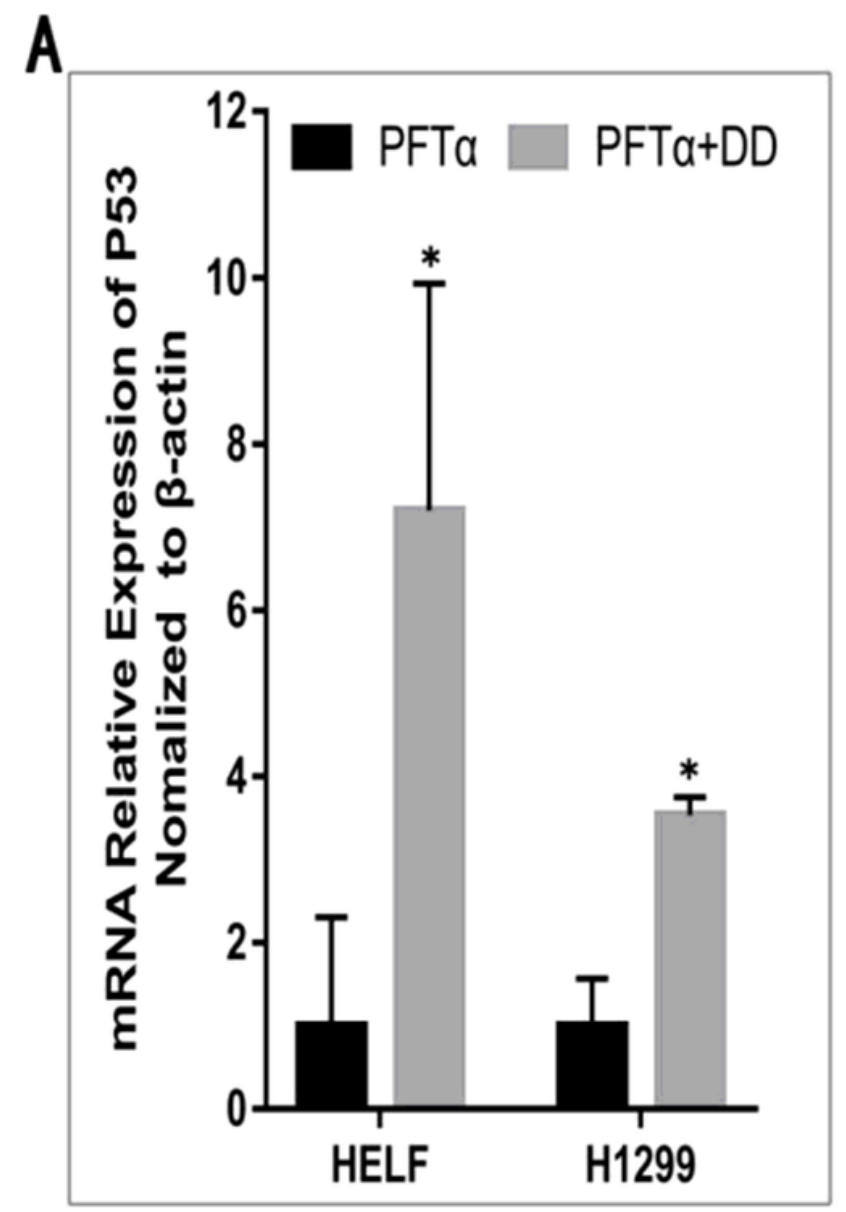

B

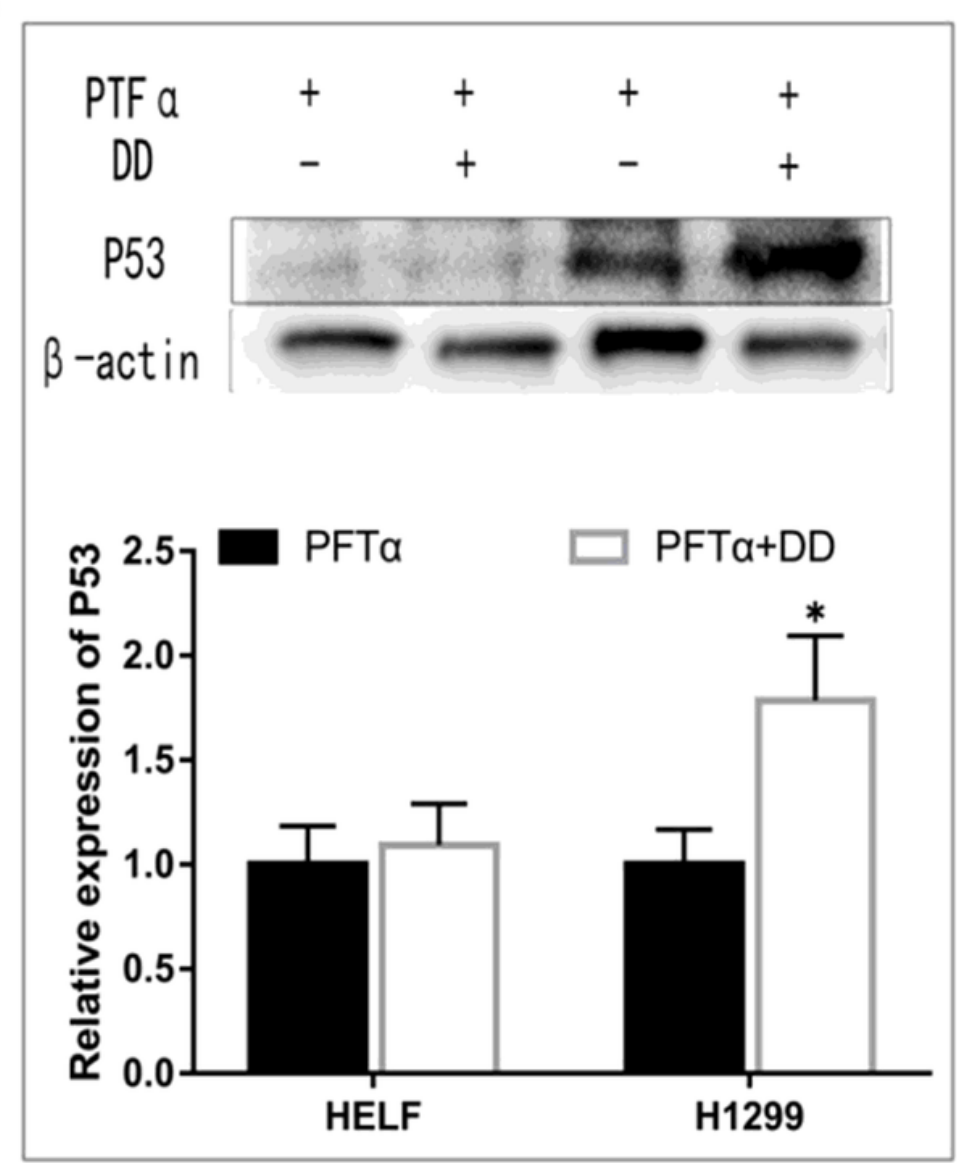

Figure 5

Daidzein-induced apoptosis is associated with increased P53 levels in HELF and H1299 cells. a mRNA expression of TP53. $b$ The protein expression of P53. Error bars represent $\pm S E$ and *P $<0.05$. 


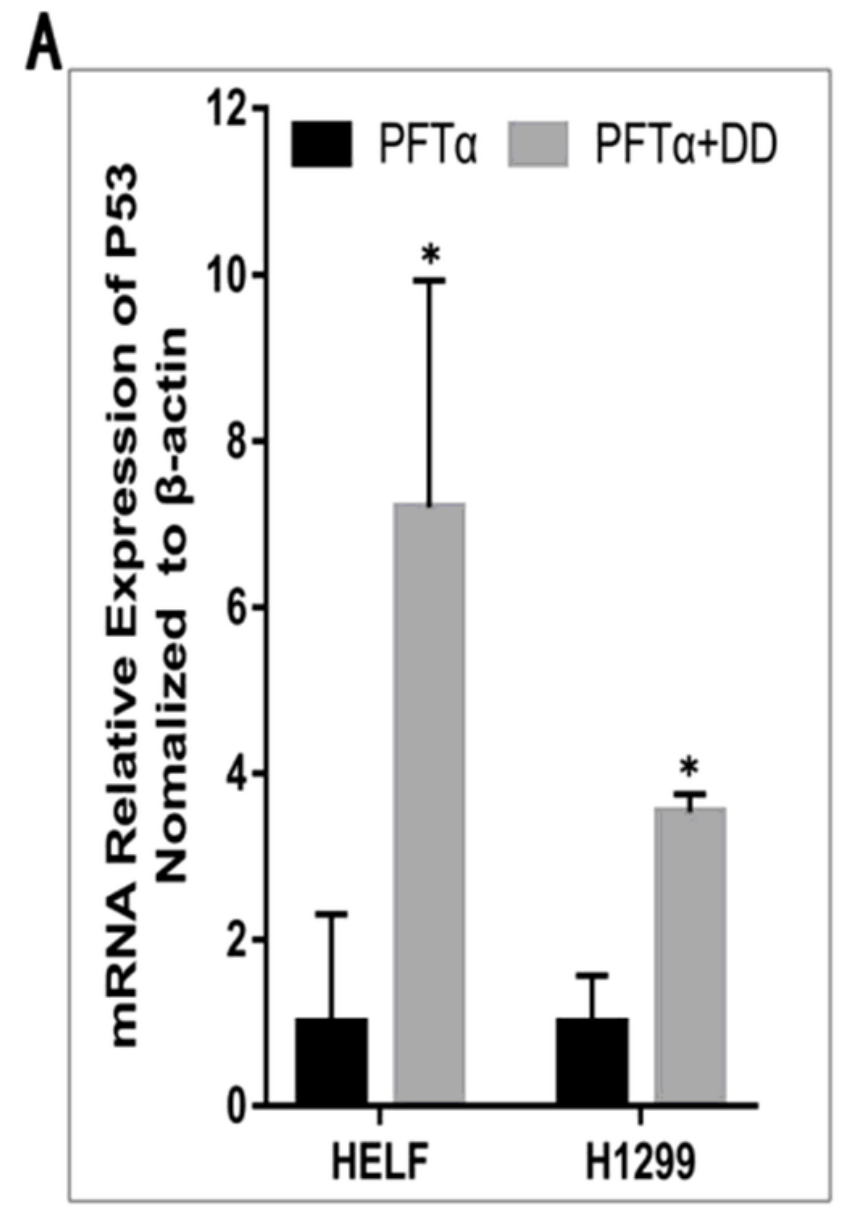

B

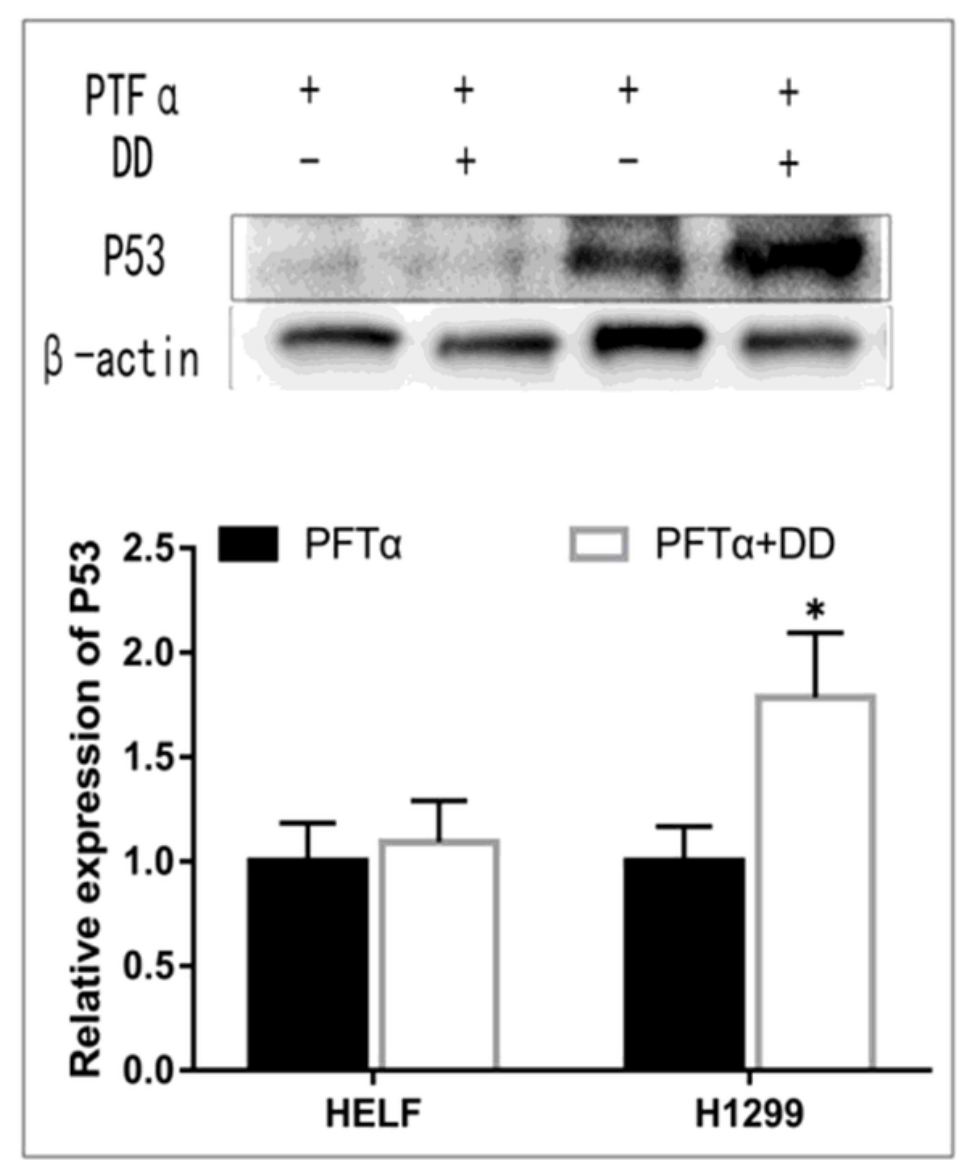

Figure 5

Daidzein-induced apoptosis is associated with increased P53 levels in HELF and H1299 cells. a mRNA expression of TP53. $b$ The protein expression of P53. Error bars represent \pm SE and * $\mathrm{P}<0.05$. 


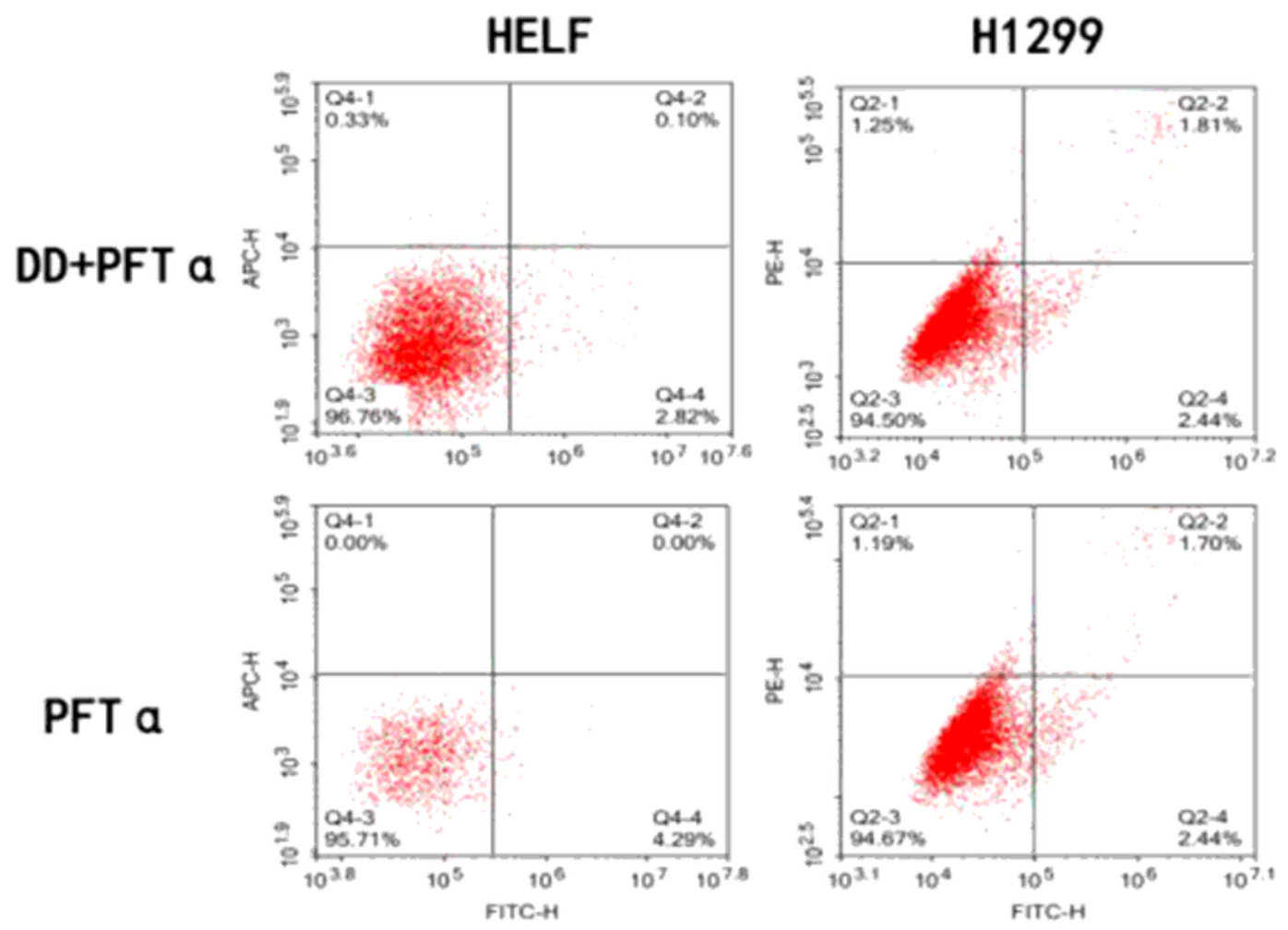

$10 \mu \mathrm{M}$ Daidzein for $6 \mathrm{~h}$

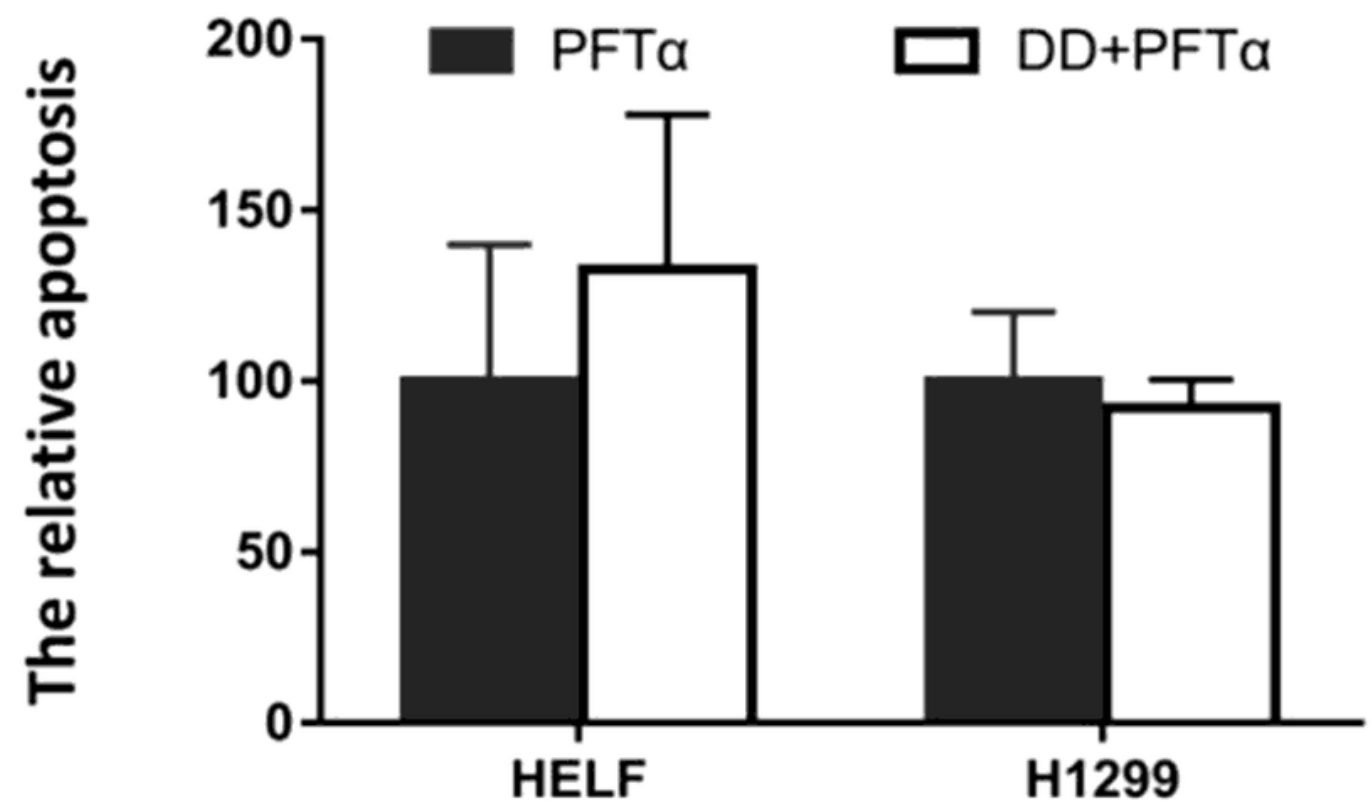

Figure 6

The effects on apoptosis in HELF and H1299 cells were induced by daidzein. The relative apoptosis was increased in the HELF cells and non-significant decrease in the $\mathrm{H} 1299$ treatment with $10 \mu \mathrm{M}$ daidzein with controlled by $10 \mu \mathrm{M}$ pifithrin-a only for $6 \mathrm{~h}$. 


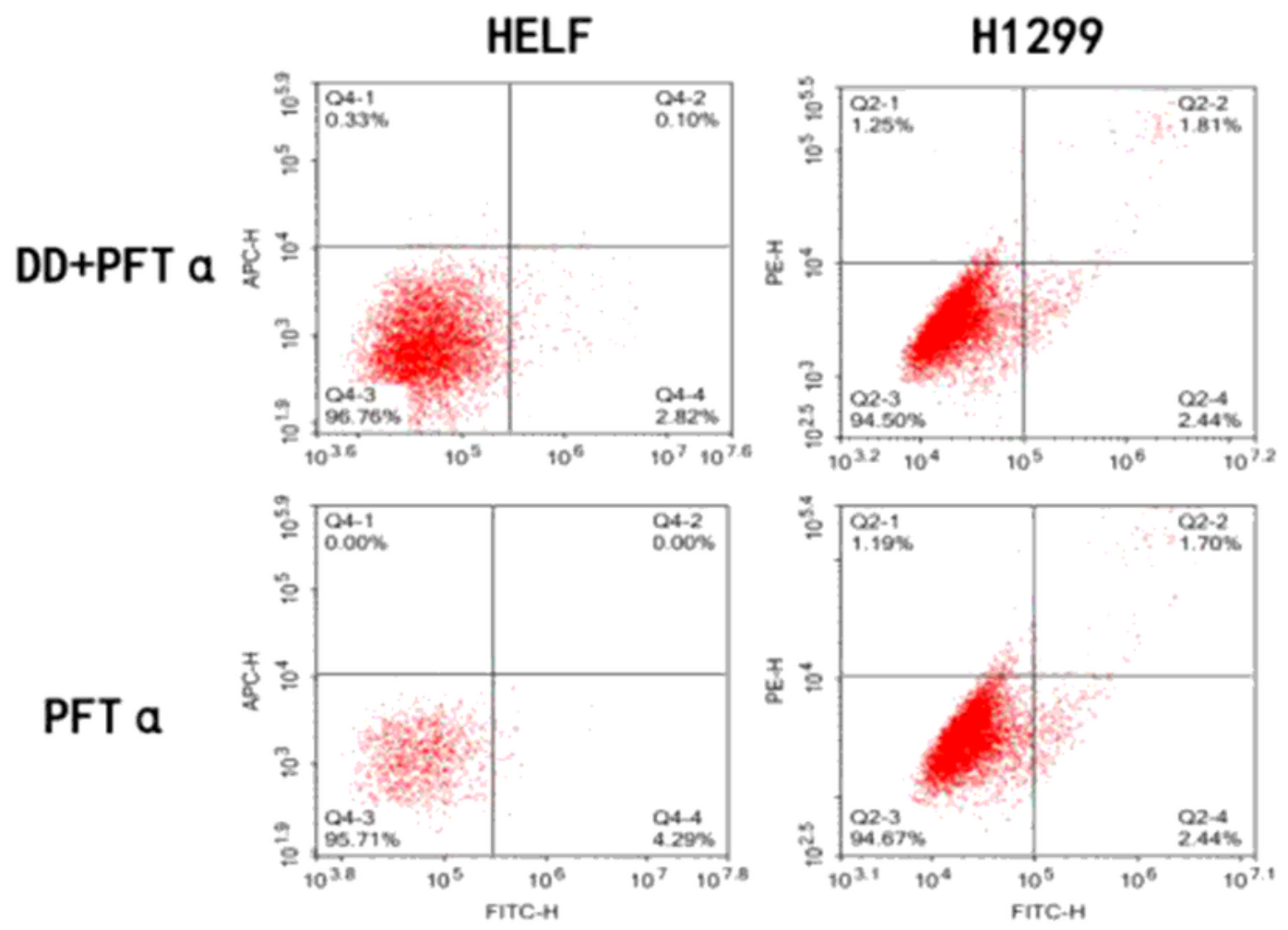

$10 \mu \mathrm{M}$ Daidzein for $6 \mathrm{~h}$

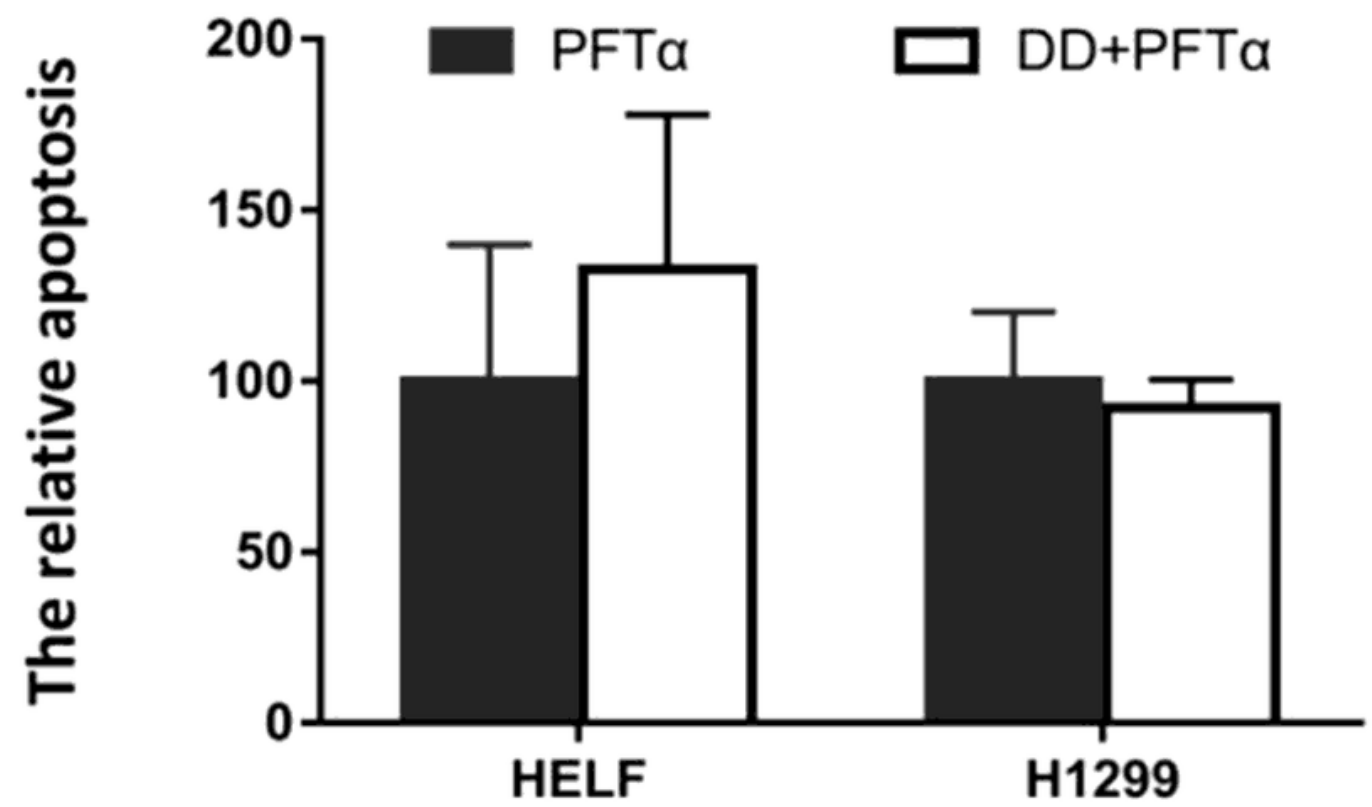

Figure 6

The effects on apoptosis in HELF and H1299 cells were induced by daidzein. The relative apoptosis was increased in the HELF cells and non-significant decrease in the $\mathrm{H} 1299$ treatment with $10 \mu \mathrm{M}$ daidzein with controlled by $10 \mu \mathrm{M}$ pifithrin-a only for $6 \mathrm{~h}$. 


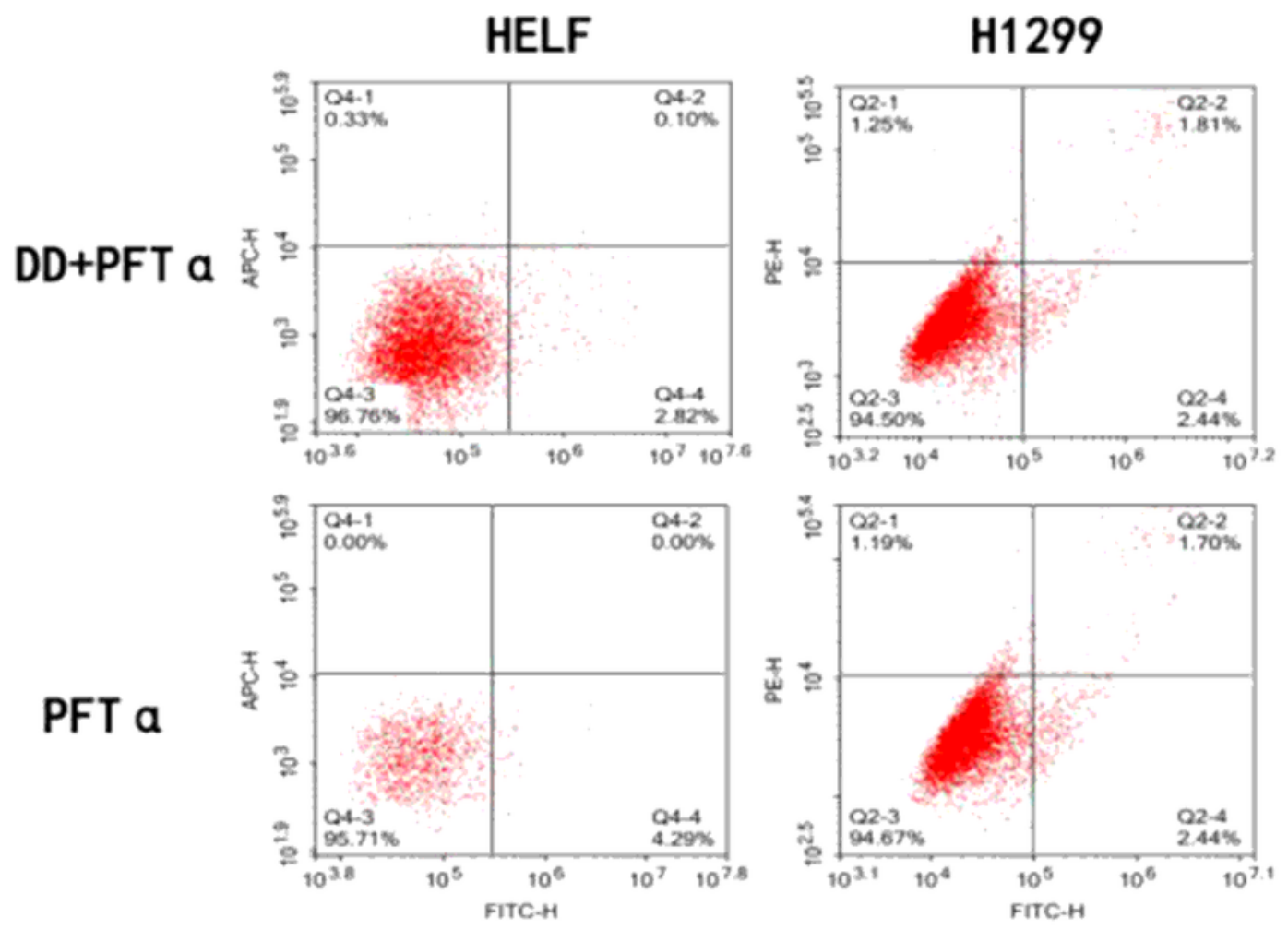

$10 \mu \mathrm{M}$ Daidzein for $6 \mathrm{~h}$

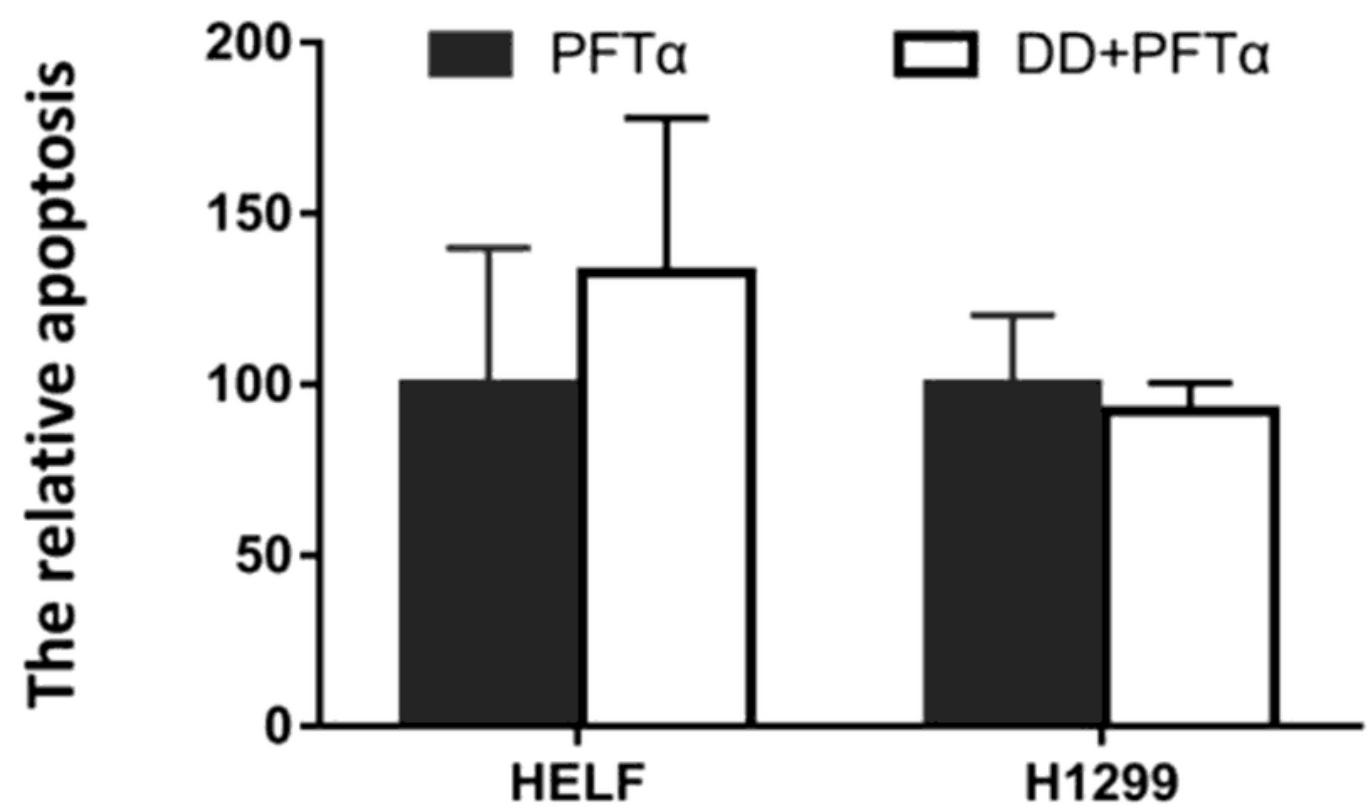

Figure 6

The effects on apoptosis in HELF and H1299 cells were induced by daidzein. The relative apoptosis was increased in the HELF cells and non-significant decrease in the $\mathrm{H} 1299$ treatment with $10 \mu \mathrm{M}$ daidzein with controlled by $10 \mu \mathrm{M}$ pifithrin-a only for $6 \mathrm{~h}$. 


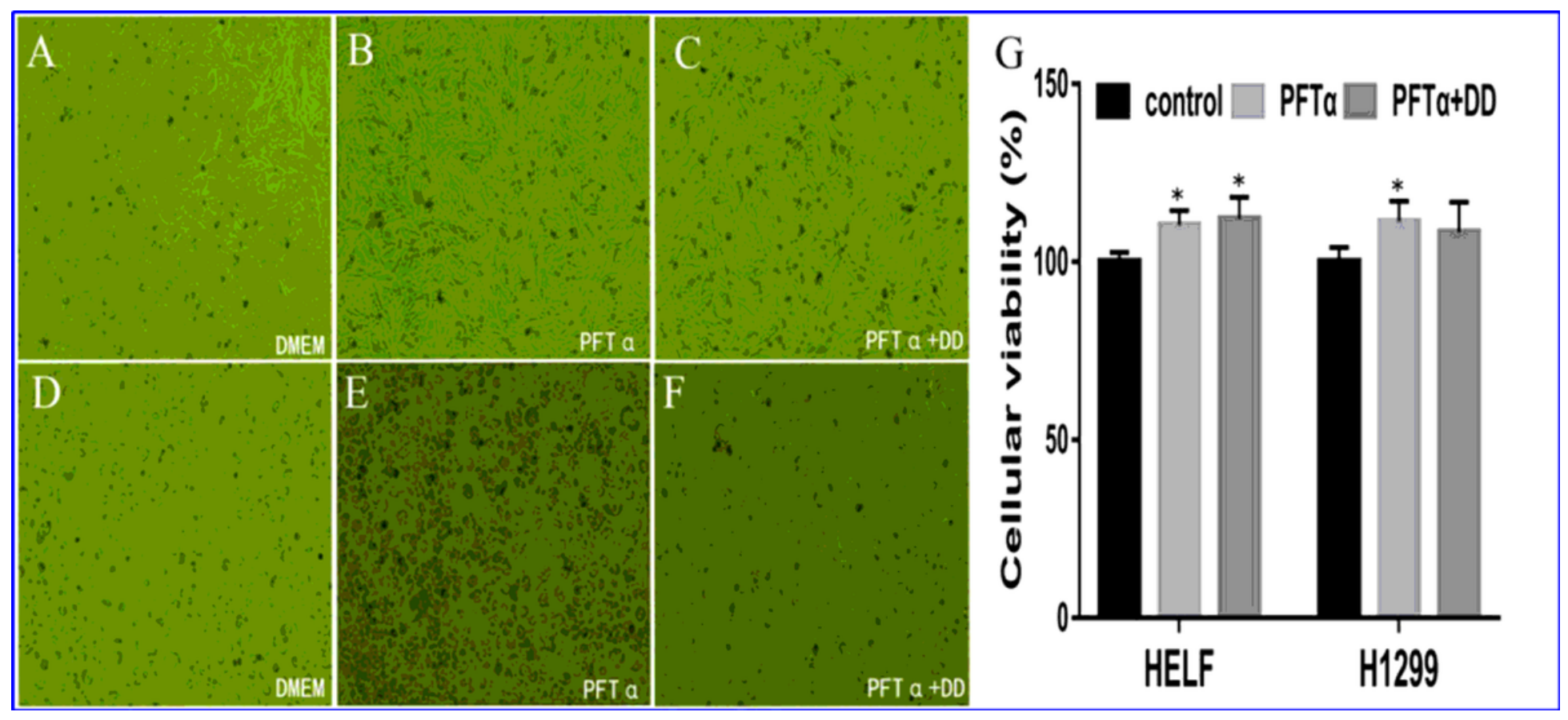

Figure 7

The proliferation status in HELF and H1299 cells after $10 \mu \mathrm{M}$ pifithrin-a treated. a, b, c HELF cells were cultured in the DMEM medium, $10 \mu \mathrm{M}$ pifithrin-a, $10 \mu \mathrm{M}$ pifithrin-a, and $10 \mu \mathrm{M}$ daidzein, respectively. Representative images after 6 hours of incubation are shown. $d$, $f$ HELF cells were cultured in the DMEM medium, $10 \mu \mathrm{M}$ pifithrin- $\mathrm{a}, 10 \mu \mathrm{M}$ pifithrin- $\mathrm{a}$, and $10 \mu \mathrm{M}$ daidzein, respectively. Representative images after 6 hours of incubation are shown. $g$ The relative cell count was evaluated by cell counting chamber. $* \mathrm{P}<0.05$

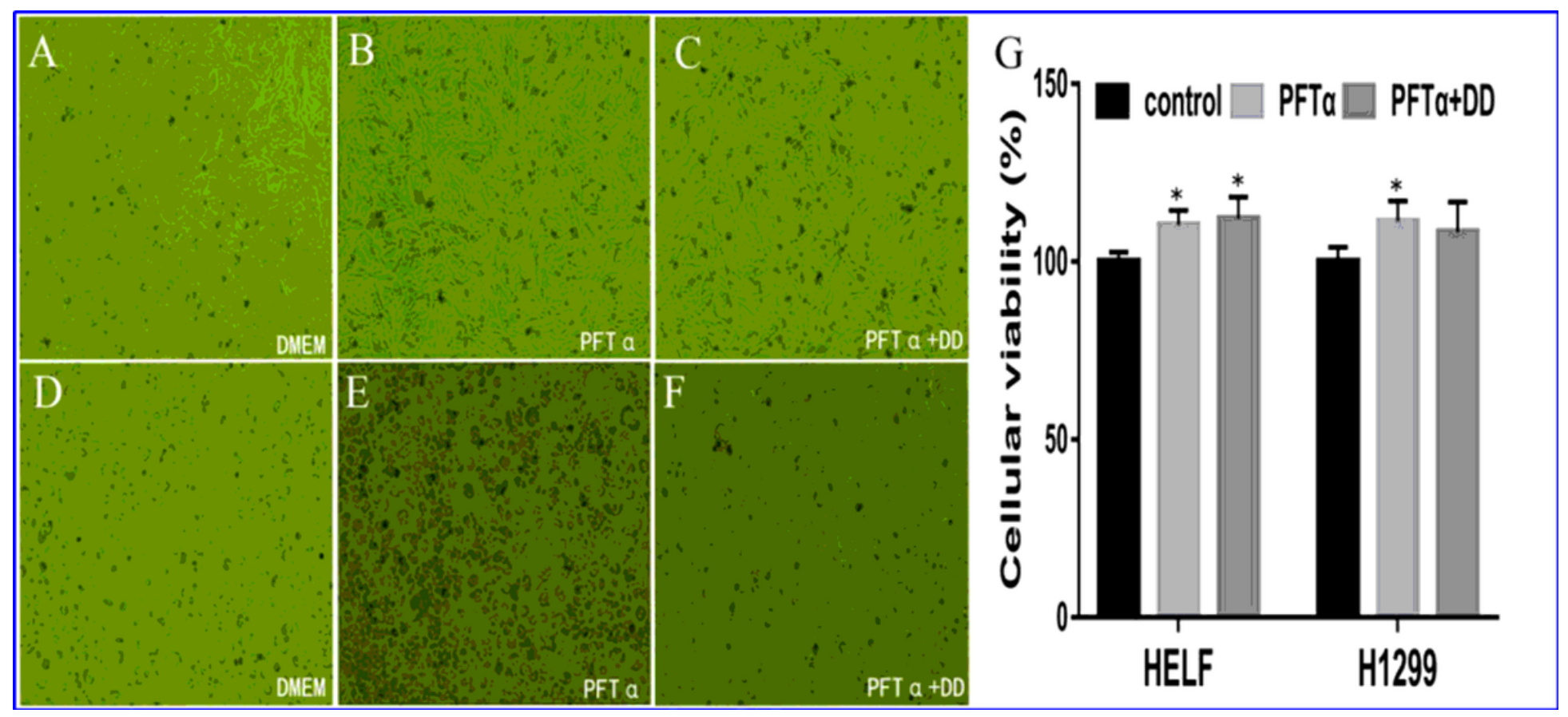

Figure 7 
The proliferation status in HELF and H1299 cells after $10 \mu \mathrm{M}$ pifithrin-a treated. a, b, c HELF cells were cultured in the DMEM medium, $10 \mu \mathrm{M}$ pifithrin-a, $10 \mu \mathrm{M}$ pifithrin-a, and $10 \mu \mathrm{M}$ daidzein, respectively. Representative images after 6 hours of incubation are shown. $d$, $f$ HELF cells were cultured in the DMEM medium, $10 \mu \mathrm{M}$ pifithrin- $\mathrm{a}, 10 \mu \mathrm{M}$ pifithrin- $\mathrm{a}$, and $10 \mu \mathrm{M}$ daidzein, respectively. Representative images after 6 hours of incubation are shown. $g$ The relative cell count was evaluated by cell counting chamber. $* \mathrm{P}<0.05$

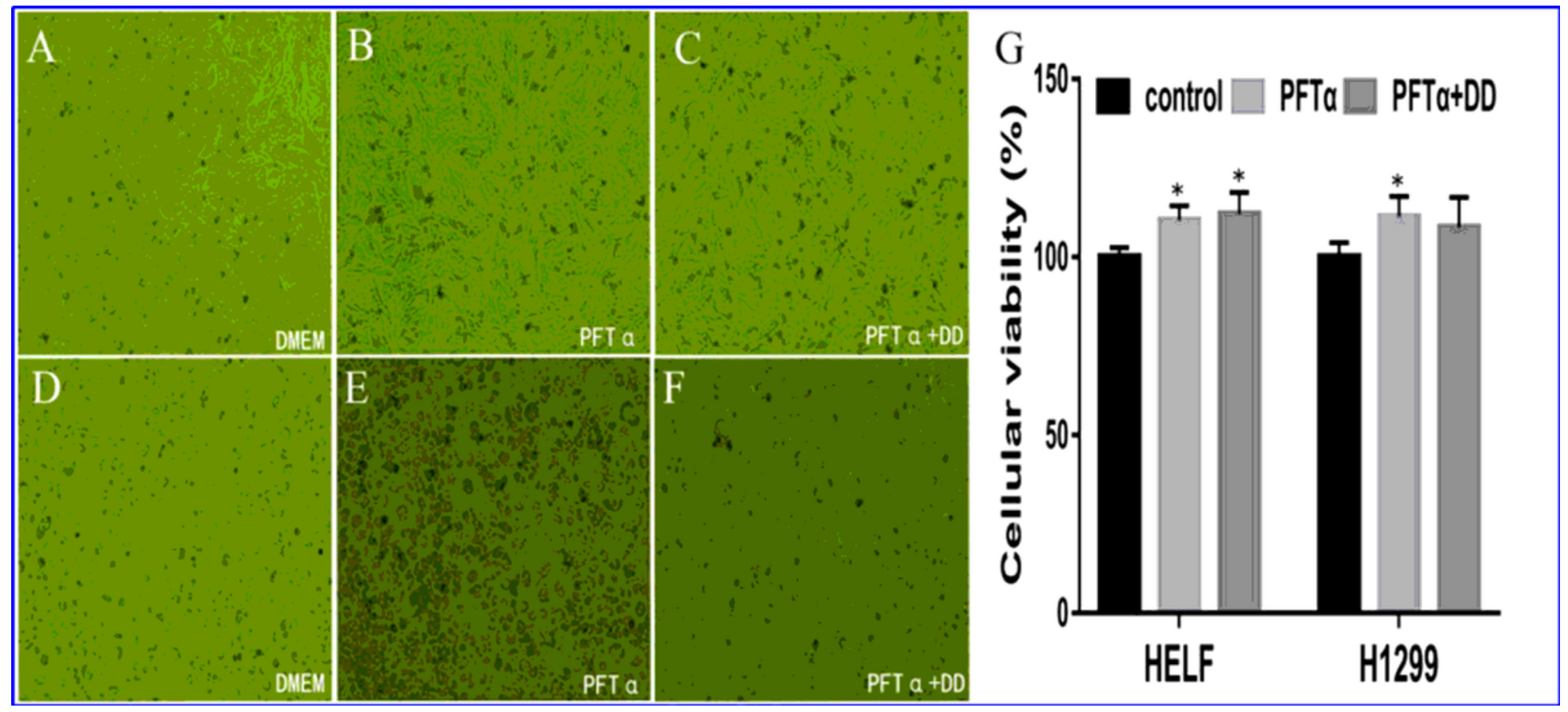

\section{Figure 7}

The proliferation status in HELF and H1299 cells after $10 \mu \mathrm{M}$ pifithrin-a treated. a, b, c HELF cells were cultured in the DMEM medium, $10 \mu \mathrm{M}$ pifithrin- $\mathrm{a}, 10 \mu \mathrm{M}$ pifithrin-a, and $10 \mu \mathrm{M}$ daidzein, respectively. Representative images after 6 hours of incubation are shown. $d$, $f$ HELF cells were cultured in the DMEM medium, $10 \mu \mathrm{M}$ pifithrin- $\mathrm{a}, 10 \mu \mathrm{M}$ pifithrin- $\mathrm{a}$, and $10 \mu \mathrm{M}$ daidzein, respectively. Representative images after 6 hours of incubation are shown. $g$ The relative cell count was evaluated by cell counting chamber. $\star P<0.05$ 